\title{
Effects of water stress on phenolic content and antioxidant activity of African nightshades
}

\author{
ODHIAMBO PETER OKELLO ${ }^{1}$, JOSEPH P. ONYANGO GWEYI ${ }^{2, \vartheta}$, MILDRED PAULINE NAWIRI ${ }^{3}$, \\ WINFRED MUSILA ${ }^{4}$ \\ ${ }^{1}$ School of Agriculture and Enterprise Development, Kenyata University. Nairobi, Kenya \\ ${ }^{2}$ Department of Agricultural Science and Technology, Kenyata University. Nairobi, Kenya. `email: josephonyango2002@yahoo.co.uk; \\ gweyi.joseph@ku.ac.ke \\ ${ }^{3}$ Department of Chemistry, Kenyata University. Nairobi, Kenya \\ ${ }^{4}$ Department of Plant Sciences, Kenyata University. Nairobi, Kenya
}

Manuscript received: 30 November 2016. Revision accepted: 2 May 2017.

\begin{abstract}
Okello OP, Gweyi JPO, Nawiri Mp, Musila W. 2017. Effects of water stress on phenolic contents and antioxidant activity of African nightshades. Biofarmasi J Nat Prod Biochem 15: 74-90. This study aimed to map out the distribution of different African Nightshade species in Siaya and Kisii Counties of Kenya and determine the water stress effect on total antioxidant capacity and total phenolic content of two selected African nightshade, namely, giant nightshade (Solanum scabrum) and black nightshade (Solanum villosum). Before selecting the two varieties, the study involved field visits, mapping of nightshades present, and administering semistructured questionnaires to farmers to determine the indigenous vegetables being grown, the nightshade species grown, and factors affecting their production. The experiments were conducted both in the field and in greenhouse conditions. Watering intervals were at 15 cbars, 50 cbars, and 85 cbars. Data on the number of secondary buds, leaf area, shoot height, and shoot and root dry weights were gathered. The total antioxidant capacity and the total phenolic content were recorded using the DPPH radical scavenging method and the Folin-Ciolcalteu method, respectively. The data collected were subjected to ANOVA. In both counties where production was $100 \%$ under small scale, Solanum scabrum was the main variety grown in Siaya County (36\%), while in Kisii, the main variety was Solanum villosum $(32 \%)$. There were significant differences $(\mathrm{P} \leq 0.05)$ among treatments in leaf area, plant height, shoot biomass, number of secondary buds, leaf and root total phenolic content, and leaf and root antioxidant activity. At all stress levels, Solanum scabrum exhibited the tallest plant with a maximum height of $45.17 \mathrm{~cm}$ at $15 \mathrm{cbars}$. At the same time, Solanum villosum had the shortest plants at all stress levels, with the shortest one being recorded at $16.65 \mathrm{~cm}$ at 85 cbars. S. scabrum also had the highest root dry weight (7.78g), shoot dry weight $(50.78 \mathrm{~g})$, and highest leaf area $(304.45 \mathrm{~cm} 2)$. However, Solanum villosum had the highest number of secondary buds at all stress levels, with the highest being 24 at 15 cbars. Concerning phytochemicals, Solanum villosum had a higher concentration of both the total phenolics and antioxidant activity in the shoots $(46.41 \mathrm{~g} \mathrm{GAE} / \mathrm{Kg}$ DM total phenolic content and 52.68\% total antioxidant activity). Meanwhile, Solanum scabrum had a higher concentration in the roots $(25.06 \mathrm{gGAE} / \mathrm{Kg}$ DM total phenolic content and $27.18 \%$ total antioxidant activity). Water stress causes a decline in all growth parameters but increases phytochemical accumulation in nightshade accessions grown. Therefore, it is suggested that for better yields, irrigation should be performed at every 15 cbars; however, for adequate phytochemical accumulation, the irrigation should be carried out at 50 cbars. Further research must explore and quantify other phytochemical components affected by different watering regimes.
\end{abstract}

Keywords. African nightshades, antioxidant activity, phenolic contents, water stress

\section{INTRODUCTION}

African nightshades (Solanum spp.) are among the African indigenous leafy vegetables reported to be an important source of antioxidants such as lycopene, phenolics, and vitamin $\mathrm{C}$ in the human diet. Antioxidants have been linked to reduced risk of prostate and various other forms of cancer and heart disease and boosting the immune system of HIV/AIDS patients (Maundu et al. 1999). Growing demand for dietary antioxidants has triggered the search for newer, economic, nutritional, and multifunctional sources that possess free radical scavenging potential (Imungi 2002). With cancer and HIV/AIDS becoming a threat to economic development, a shift has been seen in food consumption trends both in urban centers and rural areas of Kenya, with a majority opting for traditional vegetables. About $56 \%$ of the population of
Kenya lives below the poverty line, and about $50.6 \%$ of the population lack access to adequate food; moreover, even the little they get is of poor nutritional value and quality (GoK 2004). The high poverty levels manifest in malnutrition and poor health, mainly for most Kenyan rural populations. The poverty situation has been worsened by the high prevalence of HIV/AIDs, where 2.5 million Kenyans are already infected with an annual infection rate of 200,000 (GoK 1999). Nevertheless, Kenya is endowed with high agricultural biodiversity like African nightshades (ANS), which could significantly manage HIV/AIDS infected and affected persons (Irungu 2007).

African nightshades have high micronutrient content, medicinal properties (Maundu et al. 1999), and several agronomic advantages and contribute to food and nutrition security and income generation (Schippers 2002). African nightshades are indigenous or traditional vegetables whose 
leaves, young shoots, and flowers are consumed. Communities in Western Kenya have used these vegetables for a long time (Imungi 2002). Though they have been underutilized or neglected for a long time, there has been a renewed interest in African nightshades by the policymakers and the international community to realize that these vegetables have a prominent benefit that has yet to be exploited (Olembo et al. 1995).

Phytochemical studies have revealed that the plant contains glycoalkaloids (solanine, solamargine, solanigrine, and solasodine), steroidal glycosides ( $\beta$-solamargine, solasonine, and $\alpha, \beta$ - solansodamine), steroidal saponins (diosgenin), steroidal genin (gitogenin), tannin and polyphenolic compounds (Oh et al. 2010). In response to drought, plants typically accumulate a wide range of antioxidants, including enzymatic antioxidants (peroxidases, superoxide dismutase, and catalase) and nonenzymatic antioxidants to quench the reactive oxidative species (ROS) induced by water stress (Mittler 2005). In many plant species, water stress also induces some phytochemicals, including a-tocopherol, b-carotene, and flavonoids, in many plant species (Velikova et al., 2000).

A plant is affected by several stress factors (biotic and abiotic), and any particular factor may reinforce or compensate for the effects of others. The current climate change depicted by local changes and annual variations in the precipitation expose many plants to water stress (Gorai et al. 2010). To prevent the accumulation of activated oxygen species (AOS), plants have evolved highly efficient antioxidative defenses composed of both enzymatic and non-enzymatic antioxidants (Foyer et al. 1994). These products are good health indices whose quantities need to be documented. Therefore, this research sought to assess ANS responses to water stress effects on plant distribution based on the phytochemicals produced. Plant phytochemicals, for example, phenolics, are responsible for plant adaptation to variable environments.

The objective of this study was (i) To document and map out the distribution of African Nightshade species in Siaya and Kisii counties of Kenya. (ii) To evaluate biomass yields of African Nightshades species under different watering regimes. (iii) To determine the concentration of phytochemicals in cultivated species concerning soil water status and determine the trade-off between yield and phytochemicals in plant shoots.

\section{MATERIALS AND METHODS}

\section{The study area}

Two approaches to research were performed. Firstly, a field survey for preliminary data gathering was carried out in Siaya and Kisii Counties of Kenya in February (long rainy season) and August (short rainy season) of 2014. The survey covered determining nightshade species grown by farmers in the two counties. Moreover, the phytochemical concentration of the samples collected during the mapping period was also confirmed, and the soil moisture content at the time of mapping. In Siaya County, which has an area of approximately $2,530.5 \mathrm{Km}^{2}$, the survey covered the Agoro
Oyombe, Ramba, Dominion farms, Yala, and Gem Ulamba areas. The county lies between latitude $0^{\circ} 26^{\prime}$ to $0^{\circ} 18^{\prime} \mathrm{N}$ and longitude $33^{\circ} 58^{\prime} \mathrm{E}$ and $34^{\circ} 33^{\prime} \mathrm{W}$, receiving annual rainfall between $1,170 \mathrm{~mm}$ and $1,450 \mathrm{~mm}$, with an average temperature of $21.75{ }^{\circ} \mathrm{C}$ and a range of from $15{ }^{\circ} \mathrm{C}$ to 30 ${ }^{0} \mathrm{C}$. On the other hand, Kisii County, located in Western Kenya with approximately $1,317.4 \mathrm{Km}^{2}$, and the coverage includes Kisii town, Minyinkwa, and Keumbu. Kisii receives frequent convectional rains and enjoys a great highland climate because it is located between $0^{\circ} 41^{\prime} 0^{\prime \prime} \mathrm{S}$, $34^{\circ} 46^{\prime} 0$ 'E. Thus, it enjoys two rainfall seasons; short rains (September-November) and long rains (February-June), and receives rainfall amount of over $1,500 \mathrm{~mm}$ per annum with temperatures ranging from $16{ }^{\circ} \mathrm{C}$ to $27{ }^{\circ} \mathrm{C}$. The second approach was field experiments in Kenyatta University Research and demonstration farm in Nairobi County. Kenyatta University is located between $1^{\circ} 10^{\prime} 52$ 'S, $36^{\circ} 55^{\prime} 38^{\prime \prime} \mathrm{E}$ and $1.1^{\circ} \mathrm{S}, 36.9^{\circ} \mathrm{E}$, receives rainfall of about $750 \mathrm{~mm}$ with temperatures between $25^{\circ} \mathrm{C}$ to $33^{\circ} \mathrm{C}$.

\section{Field survey}

This preliminary data collection involves qualitative and quantitative data. The qualitative data collection is performed through direct discussions and interviews with public and private sector key stakeholders in the production and marketing of African nightshades, such as traders, farmers, and agricultural extension officers. The quantitative data collection is performed by analyzing semi-structured questionnaire results from randomlyselected 20 traders from various key markets and 60 farmers from different farms who are directly engaged in African nightshade production and marketing.

The questionnaire for traders involves some inquiries about the source of nightshade, the effect of rainfall, market availability, etc.; in contrast, inquiries for farmers involve some inquiries about the scale of production, dependence on rainfall and or irrigation, the effect of drought to taste, and the rationale of nightshade production. To ensure the validity of the questionnaire, several preliminary tests and adjustments were carefully conducted, and direct observation and informal interviews complement the questionnaire. Thus, plant samples from farmers were also collected and analyzed on the concentration of phytochemicals.

\section{The greenhouse and field experiment Materials}

Open field at Kenyatta University's main campus and a demonstration farm was selected as the place for the experiment in addition to the greenhouse. The experiment materials, such as seeds and fertilizers, were obtained from Kiambu agro vets. Loamy soils $(4.5 \mathrm{~kg})$ and DAP (Diammonium phosphate) fertilizer at a $5 \mathrm{~g} / 5$ liters plastic pot rate were prepared for the greenhouse experiment.

\section{Tensiometer installation}

The installation included a portable Irrometer Model P tensiometer for the spot check of the soil moisture conditions. The measurement was made from $24 \mathrm{~cm}$ root depth at a 3-hour interval. Treatments included irrigation at 
15 cbars, 50 cbars, and 85 cbars. If the soil moisture conditions changed, irrigation began with 5 cbars referring to the soil moisture capacity.

\section{The greenhouse experiment and design}

The experiment started with preliminary preparation by transplanting six healthy seeds into an individual pot; watering them daily until they were ready for the experiment. One week elapsed, and four plantlets remained in each pot. The experiment began with treatment with a different range of water patterns, i.e., low (15 cbars), moderate (50 cbars), and high ( 85 cbars). The treatments were replicated four times, and the pots were randomly rearranged every week to remove errors that greenhouse conditions might generate. Unexpected weeds in the pots were removed by hand. At the end of the third week, various parameters data collection was performed thoroughly.

\section{The field experiments}

This was carried out at the Kenyatta University Research and demonstration farm in two distinct seasons. The first season (long rains) was between February and May in 2014, and the second one (short rains) was carried out between August and October the same year. The experiment was replicated four times in a Randomized Complete Block Design (RCBD) on split plots. The main plot was the two nightshade accessions (S.villosum and S.scabrum), and the subplots underwent watering patterns at 15,50 , and 85 cbars, respectively.

\section{Data collection}

Parameters collected are all related to growth in different treatments during six weeks, i.e., length of the root, length of the shoot length, weight of the fresh and dry plant, weight of the fresh and dry roots, and area of the leaves.

\section{Number of secondary shoots}

The number of secondary shoots emanating from the stem was counted and recorded.

\section{Shoot height}

Shoot height was measured using a meter rule from the stem base up to the shoot apex. This was done before uprooting the plant to counteract errors due to loss of turgidity.

\section{Leaf area}

Leaf area was determined using the formula $\mathrm{LA}=0.73$ $\left(\mathrm{L}_{\mathrm{L}} \mathrm{X} \mathrm{W}_{\mathrm{L}}\right)$, where $\mathrm{L}_{\mathrm{L}}$ is the leaf length, and $\mathrm{W}_{\mathrm{L}}$ is the maximum width measured for each leaf on each plant. Four leaves were randomly measured, and leaf area was determined from the averages.

\section{Root and Shoot fresh weights}

The whole plant was uprooted, rinsed, and separated into shoot and root, and the weights were measured with an electronic weighing balance. Obtained samples were airdried for two days before being taken to the laboratory for phytochemical analysis.
Table 1. The reagent used in the study

\begin{tabular}{|c|c|c|}
\hline Chemical reagent & $\begin{array}{l}\text { Percentage } \\
\text { purity }\end{array}$ & Company of origin \\
\hline$\overline{\text { Gallic acid }}$ & 99.9 & Aldrich, Germany \\
\hline Methanol & 99.9 & Scharlab S.L, Spain \\
\hline $\begin{array}{l}\text { Folin and Ciocalteu } \\
\text { phenol reagent }\end{array}$ & 99.7 & $\begin{array}{l}\text { BDH Limited, Poole- } \\
\text { England }\end{array}$ \\
\hline Sodium Carbonate & 99.5 & $\begin{array}{l}\text { Central drug house }(\mathrm{P}) \\
\text { Limited, New Delhi-India }\end{array}$ \\
\hline $\begin{array}{l}\text { PPH(Diphenyl picryl } \\
\text { ydrazyl) }\end{array}$ & 99.9 & Sigma Aldrich, Germany \\
\hline
\end{tabular}

\section{Reagents used}

Reagents used during the phytochemical analysis are shown in Table 1.

\section{Preparation of plant materials for phytochemical analysis}

The plant shoots and roots resulting from the experimental pots were dried in an oven for 48 hours and measured for their dry weight. Electric grinders were then used to separate the samples; five grams of the sample were taken and added with $50 \mathrm{~mL}$ of methanol and kept for 60 hours while covered with aluminum foil. The results were then filtered using Whatman filter paper No. 1, in which the filtrate was then kept in disposable sampling tubes in a freezer for further analysis.

\section{Analysis of total phenolic content}

Folin-Ciocalteu method (Rispail et al. 2005) was used in determining the total phenol content of the extracts by using Gallic acid as a standard; $0.5 \mathrm{~g}$ Gallic acid was dissolved in $10 \mathrm{~mL}$ of methanol and diluted using distilled water to $1000 \mathrm{~mL}$ equivalent to $500 \mathrm{ppm}$; and subsequently to $250 \mathrm{ppm}, 125 \mathrm{ppm}, 62.5 \mathrm{ppm}, 31.15 \mathrm{ppm}$, and 15.625 ppm. Each $1 \mathrm{~mL}$ of the different Gallic acid solutions was pipetted into separate test tubes, and $4 \mathrm{~mL}$ of distilled water was added, continued by $0.2 \mathrm{~mL}$ Folin reagent, and mixed well. After 10 minutes, $0.4 \mathrm{~mL}$ of freshly prepared sodium carbonate (prepared by adding $40 \mathrm{~g}$ of $\mathrm{Na}_{2} \mathrm{CO}_{3}$ in $200 \mathrm{~mL}$ of distilled water) was added, and the solution was incubated for 1 hour at $25^{\circ} \mathrm{C} .1 \mathrm{~mL}$ of plant extract was pipetted in a separate test tube to determine phenolic content in the plant extracts. The absorbance of each solution was determined at $765 \mathrm{~nm}$ against the blank.

Calculation of total phenolic content (TPC):

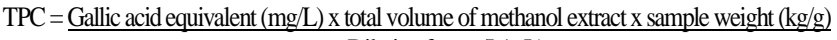
Dilution factor $(\mathrm{L} / \mathrm{mL})$

\section{Antioxidant determination}

Akter et al. (2010) analyzed the free-radical-scavenging ability of the extracts against DPPH (2, 2-diphenyl1picrylhydrazyl) free radicals. They resulted in the reactivity of the test compounds with a stable free radical providing a strong absorption band at $517 \mathrm{~nm}$ in the visible region. Next step was preparing concentration of extracts with $0.05,0.1,0.5,1.0$, and $2.0 \mathrm{mg} / \mathrm{mL}$ methanol in cuvette placed inside spectrophotometer (Analar grade). For the 
antioxidant standard, Vitamin $\mathrm{C}$ was used. One $\mathrm{mL}$ of the extract was placed in a test tube, added with $3 \mathrm{~mL}$ of methanol and $0.5 \mathrm{~mL}$ of $1 \mathrm{mM}$ DPPH in methanol, mixed, and kept for 5 minutes. A blank solution was prepared to contain the same amount of methanol and DPPH. The absorbance of the resulting solution was measured at 517 nm with a UV-vis spectrophotometer (model Cecil CE: 2041; 2000 series, Shimadzu Corp., Kyoto, Japan). The experiments were replicated three times, and the radical scavenging activity was measured as follows:

$\%$ total antioxidant activity $=\underline{\text { Absorbance }}$ Control - Absorbance sample $X 100$ Absorbance Control

\section{Data analysis}

Analysis of variance (ANOVA) was carried out using SAS statistical computer package version 9.00 TS Level 00M0 XP-PRO platform. In contrast, SPSS software version 21 was used to analyze data gathered from the survey. Means were separated using the least significance difference (LSD) test at the $95 \%$ probability level.

\section{RESULTS AND DISCUSSION}

\section{Indigenous vegetables and nightshade accessions grown} and traded in Siaya and Kisii counties

The indigenous vegetables produced in the two counties included; Vigna unguiculata, Crotalaria brevidens, Gynandropsis gynandra, Brassica carinata, Solanum, Corchorus olitorius, Amaranthus gracecizans, and Cucurbita sp. The nightshade species grown included; $S$. nigrum, S. villosum, S. americanum, S. florulentum, S. scabrum, S.grossidentatum, S. Tarderemotum, and S. nigrum (Table 2). The major indigenous vegetable grown in the two counties was nightshade at $32 \%$ and $29 \%$ for Siaya and Kisii counties, respectively.

Cowpea was the second most dominant vegetable in Siaya (20\%) and Kisii (28\%) counties, followed by Amaranthus in Siaya (18\%) and Kisii (13\%). Similar results were obtained by Maundu et al. (1999). There was variation in their diversity across the two counties for other
African indigenous vegetables, as shown in Table 2. The market share of cowpeas has reached $20 \%$, followed by nightshade at $19 \%$ and Amaranthus at $17 \%$, among the most traded African indigenous vegetables. The statistic differed in Kisii County; however, nightshade took the most shares of the indigenous vegetables traded at $43 \%$, followed by cowpea at $18 \%$ and Amaranthus at $12 \%$. The variation in production and trade levels is attributed to consumer preference, for instance, the bitter taste of each vegetable. Thus, the trade of pumpkin, jute mallow, slender leaf, spider plant, and African kale varied in the two counties. However, some consumers are cooking several African vegetables mixed to add flavor to the taste and reduce its bitterness.

As many as eight nightshade species were grown in Siaya County, the majority of which were found to be $S$. scabrum (36.15\%). Meanwhile, only seven nightshade species had been grown in Kisii County, dominated by $S$. villosum at $32.31 \%$. Dominion farm bordering Yala swamp had the wild relatives of black nightshades growing by themselves within the bushes. Some farmers, especially in Kisii County, produced the AIVs for their kitchen gardens' consumption. The dominance of S. scabrum in Siaya County is attributed to the farmers and the consumer preference. For example, because S. villosum is more bitter and has smaller leaves than S. scarbum, this has led to a general decline in $S$ villosum production and consumption in Siaya County. On the other hand, S. villosum dominates Kisii County in the form of readily-available seeds. This is because the seeds are produced from the landraces, and there is less knowledge to process seeds in agro vets form.

A field survey conducted in this study demonstrated that Siaya County was richer in diversity in African nightshade accessions than Kisii County (Figures 1 and 2). Other groups have reported similar results (Schippers 2002; Abukutsa-Onyango 2003).

During the field survey, it was observed that Siaya County was richer in diversity in African nightshade accessions as compared to Kisii County (Figures 1 and 2). The results agreed with the findings of Schippers (2002) and Abukutsa-Onyango (2003).

Table 2. Indigenous vegetables and nightshade species in Siaya and Kisii counties, Kenya

\begin{tabular}{|c|c|c|c|c|c|c|c|c|}
\hline $\begin{array}{l}\text { Indigenous vegetables } \\
\text { grown }\end{array}$ & $\begin{array}{l}\text { Siaya } \\
(\%)\end{array}$ & $\begin{array}{l}\text { Kisii } \\
(\%)\end{array}$ & $\begin{array}{l}\text { Indigenous vegetables } \\
\text { traded in market }\end{array}$ & $\begin{array}{l}\text { Siaya } \\
(\%)\end{array}$ & $\begin{array}{l}\text { Kisii } \\
(\%)\end{array}$ & $\begin{array}{l}\text { Nightshade accessions } \\
\text { grown }\end{array}$ & $\begin{array}{l}\text { Siaya } \\
(\%)\end{array}$ & $\begin{array}{l}\text { Kisii } \\
(\%)\end{array}$ \\
\hline Vigna unguiculata & 20 & 28 & Vigna unguiculata & 20 & 18 & S. nigrum & 9 & 15 \\
\hline Crotalaria brevidens & 5 & 10 & Crotalaria brevidens & 3 & 4 & S. villosum & 21 & 32 \\
\hline Gynandropsis gynandra & 2 & 6 & Gynandropsis gynandra & 12 & 7 & S. americanum & 5 & 4 \\
\hline Brassica sp. & 5 & 3 & Brassica $\mathrm{sp}$ & 7 & 3 & S. florulentum & 12 & 4 \\
\hline Solanum sp. & 32 & 29 & Solanum sp. & 19 & 43 & S. scabrum & 36 & 25 \\
\hline Corchorus olitorius & 8 & 9 & Corchorus olitorius & 12 & 8 & S.grossidentatum & 4 & 4 \\
\hline Amaranthus gracecizans & 18 & 13 & Amaranthus gracecizans & 17 & 12 & S. tarderemotum & 4 & 0 \\
\hline Cucurbita sp. & 10 & 2 & Cucurbita sp. & 10 & 5 & S. nigrum & 9 & 15 \\
\hline
\end{tabular}




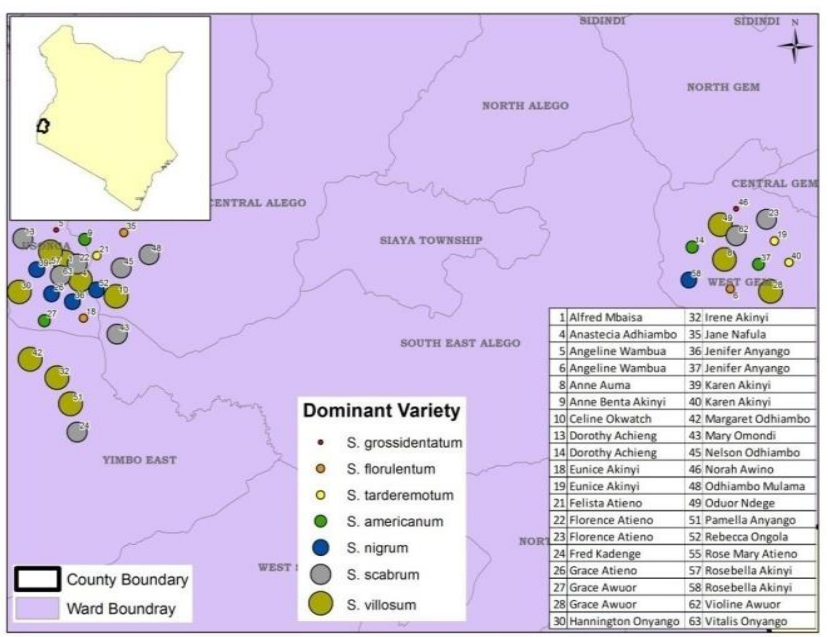

Figure 1. Nightshade accessions in Siaya County, Kenya

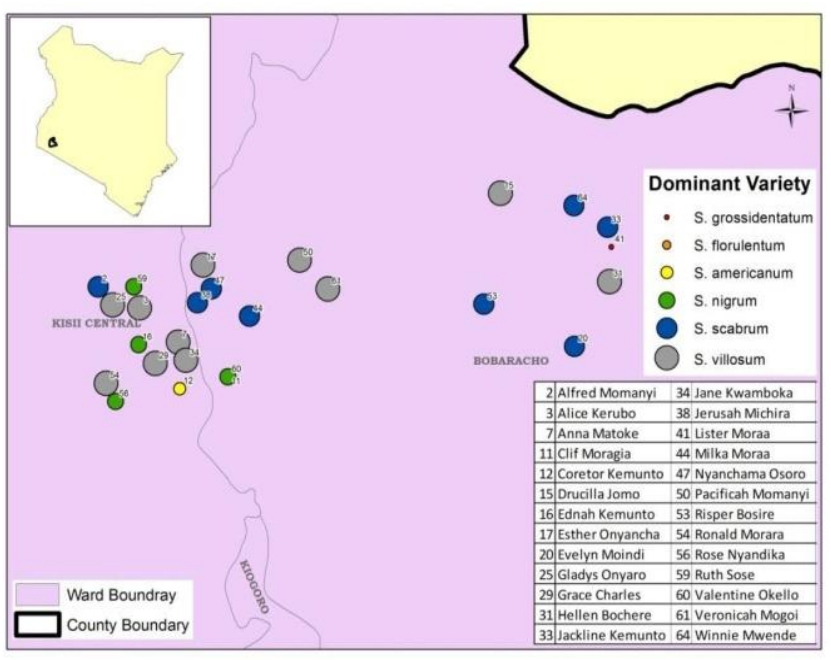

Figure 2. Nightshade accessions in Kisii County, Kenya

Some of the vegetable species were not preferred by certain farmers. They described them as tasting very bitter, except for the Giant nightshade (Solanum scabrum), which dominates most farms in Siaya County. The bitterness is probably associated with a higher degree of phytochemical accumulation. Hence, they were the most preferred by HIV/AIDS patients within Siaya County (Irungu et al. 2007). Giant nightshade was introduced and recommended by the World bank in 2012. Although common, its leaf's prolificacy tends to reduce faster after the first harvest than other grown accessions.

In Kisii County, wild relatives of black nightshade were found along the hedges of live fences, where they were considered to be used for herbal medicine rather than a vegetable source. The Solanum villosum is most preferred by consumers, thus dominating most farms in the Kisii region. Other accessions found in the two counties were mapped. Solanum scabrum and Solanum villosum were sold in all Siaya markets, in contrast to the Solanum villosum variety sold only in the Kisii market. Seventy-two point seven percent of traders in Siaya County sourced the ANS from their farms, while $27.3 \%$ had them supplied from other areas such as Kadenge, Anduro, Awello, and Umalla. Forty percent of traders in Kisii County were producers, while $60 \%$ obtained the vegetables from Transmara, Kilgoris, Magena, and Kiamabundo. The production in Kisii county does not meet consumers' demand due to the fragmentation of farms to more incomegenerating crops like sugarcane. This leaves little land for ANS production. Hence, the traders import ANS from the neighboring counties to satisfy consumer demand.

\section{Gender and production system in Siaya and Kisii counties}

Table 3 showed that men and women were both involved in the production of ANS. In Siaya County, 55\% of males and $45 \%$ of females were involved in producing African nightshades. On the other hand, 15\% of males and 8 of $5 \%$ of females engaged in farming African nightshades in Kisii County.

In the two counties, the farmers produce ANS in an area below one acre on average. The irrigation system was more developed in $33.3 \%$ of Siaya County farmers, opposite to the situation of Kisii County farmers where no irrigation systems were in place. In the latter county, the entire farmers highly depend on the onset rainfall for ANS production, whereas in Siaya County, more than half the number of farmers $(57.7 \%)$ did not rely on it.

Regarding gender composition in ANS production in Siaya County, the findings differ from Abukutsa-Onyango et al. (2005). They reported that $25 \%$ of males and $75 \%$ of females were African Indigenous Vegetable (AIV) farmers. The shift in gender composition might be due to the high returns from AIV sales, high poverty, and unemployment levels in Siaya County (GoK 1999), resulting in the majority of the males turning to farm, especially the production of ANS. The demand increases are due to WHO's efforts to create awareness of the health benefit of ANS to HIV/AIDS infected patients in Siaya County, which has an HIV/AIDS prevalence rate of $17.8 \%$ (GoK 1999). All the farmers interviewed agreed that ANS fetched higher returns than exotic vegetables such as kale and cabbages, with prices escalating to $\$ 100$ per bag in certain markets such as Awelo.

Table 3. Gender and production systems in Siaya and Kisii counties, Kenya

\begin{tabular}{|c|c|c|c|c|c|c|c|c|c|c|c|}
\hline Gender & $\begin{array}{c}\text { Siaya } \\
(\%)\end{array}$ & $\begin{array}{c}\text { Kisii } \\
(\%)\end{array}$ & $\begin{array}{c}\text { Production } \\
\text { scale }\end{array}$ & $\begin{array}{c}\text { Siaya } \\
(\%)\end{array}$ & $\begin{array}{c}\text { Kisii } \\
(\%)\end{array}$ & $\begin{array}{c}\text { Irrigation } \\
\text { system }\end{array}$ & $\begin{array}{c}\text { Siaya } \\
(\%)\end{array}$ & $\begin{array}{l}\text { Kisii } \\
(\%)\end{array}$ & $\begin{array}{c}\text { Rainfall } \\
\text { Dependence }\end{array}$ & $\begin{array}{c}\text { Siaya } \\
(\%)\end{array}$ & $\begin{array}{l}\text { Kisii } \\
(\%)\end{array}$ \\
\hline Male & 55 & 15 & Below 1 acre & 100 & 100 & present & 33.3 & 0 & Dependant & 43.3 & 100 \\
\hline Female & 45 & 85 & Above 1 acre & 0 & 0 & absent & 66.7 & 100 & Not dependant & 57.7 & 0 \\
\hline
\end{tabular}




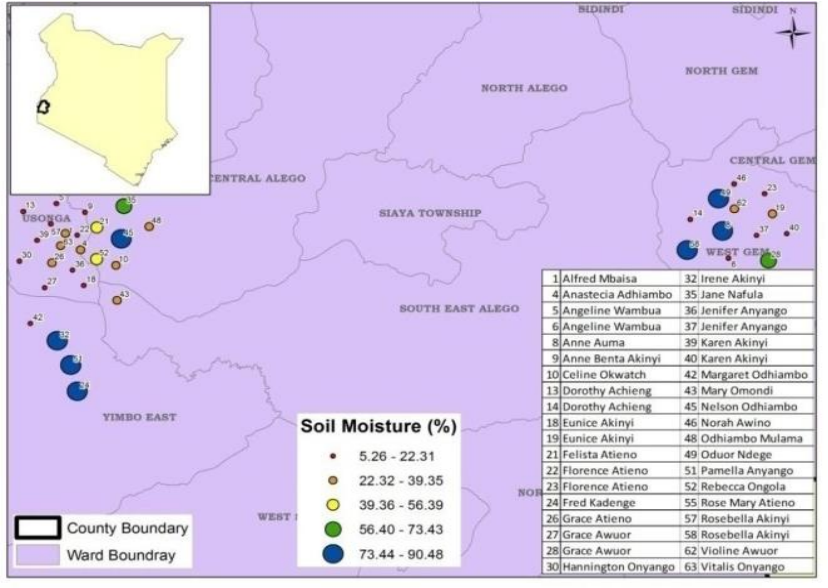

Figure 3. Soil moisture levels during the survey in Siaya County, Kenya

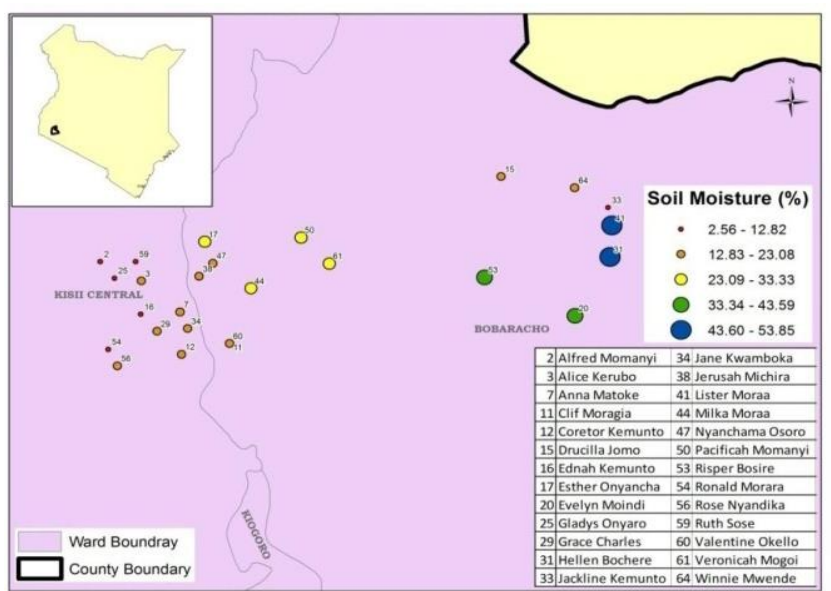

Figure 4. Soil moisture levels during the survey in Kisii County, Kenya

Production of African nightshade in Siaya County takes place along rivers or on swampy ground. The rivers provide water for irrigation as practiced in some regions, including Agoro Oyombe, Gem Kanyibuop, and Gem Kathomo. The vast Yala swamp region, especially farms surrounding the Dominion region, produce African nightshade on ever moist soil, which does not require irrigation. On the other hand, Kisii County lies within a high-altitude region and receives well-distributed rainfall throughout the year, promoting ANS production for the entire year.

Soil moisture content directly influences the phytochemical concentration among plant parts (Akinci and Lösel 2012); however, as admitted by farmers in the growing regions, the roles of specific genes on phytochemical accumulation cannot be ruled out. Areas with the highest soil moisture content were either lying within Yala Swamp (Figure 3) Yimbo East or under daily irrigation in some parts of West Gem in Siaya county. Kisii County had no irrigation practices; hence the soil moisture content may be directly influenced by differences in the altitudinal ranges and the prevailing climatic conditions. However, Kisii County recorded a lesser variation in soil moisture content than Siaya County (Figure 4).

\section{Age, education levels, and optimal African nightshade production}

There was variability regarding age, level of education, the reason behind the production of ANS, and the constraints involved in ANS production among interviewed farmers, as shown in Table 4. The majority of interviewed farmers were between the ages of 20 to 30 years, with a percentage composition of $40 \%$ and $35 \%$ in both Siaya and Kisii counties, respectively. The second dominant group was between the ages of 30 and 40 years. Their percentage composition was $24 \%$ and $33 \%$ in Siaya and Kisii counties, respectively. Among interviewed farmers, $65 \%$ in Siaya County and $51 \%$ in Kisii County had basic primary education. Twenty percent and $10 \%$ of Siaya County interviewees had secondary and college education, respectively. On the other hand, $29 \%$ and $12 \%$ of the interviewed farmers in Kisii County had secondary and college education, respectively. However, 5\% in Siaya County and $8 \%$ in Kisii County admitted having had no education. This agrees with Irungu (2007) and Mwaura et al. (2013), that ANS farmers are more educated than the other categories of traders, implying that the production of ANS is a field for those endowed with human capital.

Farmers in Siaya County began producing ANS commercially due to high consumer demand and high returns, both at $35 \%$. However, only $30 \%$ of interviewed farmers in Siaya County produced ANS due to their health benefits. In Kisii, however, the main reason behind ANS production was the high returns constituting $55 \%$ of the interviewed farmers. Only $20 \%$ of interviewed farmers in Kisii County knew about the health benefits of the African nightshades. Sixty percent and $80 \%$ of interviewed farmers in Siaya and Kisii counties

respectively admitted that the major constraint to ANS production was poor quality seeds. This is in agreement with Abukutsa-Onyango et al. (2005). Most farmers complained that seeds obtained from the agro vets were low-yielding due to the high fruiting rate after the second or third harvest.

Table 4. Age, education level, and optimal African nightshade production

\begin{tabular}{|c|c|c|c|c|c|c|c|c|c|c|c|}
\hline Age & $\begin{array}{l}\text { Siaya } \\
(\%)\end{array}$ & $\begin{array}{l}\text { Kisii } \\
(\%)\end{array}$ & $\begin{array}{l}\text { Education } \\
\text { level }\end{array}$ & $\begin{array}{l}\text { Siaya } \\
(\%)\end{array}$ & $\begin{array}{l}\text { Kisii } \\
(\%)\end{array}$ & $\begin{array}{l}\text { i Reason for } \\
\text { production }\end{array}$ & $\begin{array}{l}\text { Siaya } \\
(\%)\end{array}$ & $\begin{array}{l}\text { Kisii } \\
(\%)\end{array}$ & $\begin{array}{l}\begin{array}{l}\text { Production } \\
\text { challenges }\end{array} \\
\end{array}$ & $\begin{array}{l}\text { Siaya } \\
(\%)\end{array}$ & $\begin{array}{l}\text { Kisii } \\
(\%)\end{array}$ \\
\hline $20-30$ & 40 & 35 & Primary & 65 & 51 & Health benefit & 30 & 20 & Poor quality seeds & 60 & 80 \\
\hline $30-40$ & 24 & 33 & Secondary & 20 & 29 & Consumer demand & 35 & 25 & Technical production & 15 & 8 \\
\hline $40-50$ & 18 & 21 & College & 10 & 12 & High returns & 35 & 55 & Marketing system & 5 & 2 \\
\hline $50-60$ & 12 & 11 & None & 5 & 8 & & & & Inadequate research & 20 & 10 \\
\hline 60-Above & 6 & - & - & & & - & & & - & - & - \\
\hline
\end{tabular}


Fifteen percent in Siaya County and $8 \%$ in Kisii County had technical production problems. Twenty percent of interviewed farmers in Siaya County and $10 \%$ of interviewed farmers in Kisii County felt that inadequate research was being done to promote the production of ANS, though only $5 \%$ of interviewed farmers in Siaya County and $2 \%$ of interviewed farmers complained of poor market systems. Kenya has an unemployment rate of above $40 \%$ (GoK 1999). Hence more youths are opting for selfemployment, and one of the ways is through indulging in Agriculture. This explains the high percentages of youth involved in ANS production. The high returns due to increasing ANS demand among consumers might be a reason behind the increase in the number of youthful farmers in the two counties. Finally, the low farmers' low acquisition of tertiary education does not render them competitive enough in the ever-shrinking job market; therefore, they opt for farming (Schippers 2002; Otieno et al. 2009).

The green, leafy African nightshades contain polyphenols which have beneficial physiological effects on humans as antioxidants. They are also known to be anticarcinogenic and anti-arteriosclerotic (Imungi 2002). A study in Nairobi showed that consumption of African nightshades is associated with treating various diseases, including therapy for patients with HIV/AIDS, diabetes, high blood pressure, and other common ailments (Kimiywe et al. 2006). The majority of farmers in Siaya County are aware of this due to WHO campaigns on ANS consumption. The awareness has created an increase in demand which has alternatively led to high ANS prices in the markets in Siaya County. However, in Kisii, there has been a tradition in the consumption of ANS; hence the demand has always been there, leading to ever-increasing returns from ANS production.

The lack of quality seeds has been a major hindrance to sustainable production and utilization of indigenous vegetables (Abukutsa-Onyango 2003), as shown in Table 4. Some of the vegetables perpetuate themselves untended. They were harvested whenever they occurred, and this system of seed procurement heavily depended on the soilborne seed pool and the ability of these species to reproduce. Seed production has virtually remained in the hands of farmers for a long time, although seed sale in markets was common. For a long time, these vegetables were harvested from the wild, but as the pressure on land increased, they were domesticated and the need for quality seed set in. Usually, ANS is grown as a subsistence crop, and most farmers save their seed from season to season and sell the surplus to other growers. The quality of such seeds is poor regarding purity, viability, and seed dormancy issues. There is a need for the production and supply of quality seeds to increase yields and quantities produced to meet the unsatisfied market demands of priority indigenous vegetables, especially in urban centers (Irungu et al. 2007).

African nightshades have often been grown as intercrops with other vegetables or staples; however, there has been hardly any technical information on optimal production and appropriate cropping systems. There has been a lack of agronomic and preparation packages, and access to technical information has been very limited. Therefore, extension workers have limited knowledge to advise African nightshade growers. This necessitates research on optimal production packages for African nightshades and recipe development.

The marketing of African nightshade vegetables has been poorly organized, leading to significant product losses in transit or markets. The major constraint of marketing was the abundance of ANS vegetables during the rainy season leading to low prices and scarcity during the dry season. This calls for identifying and creating markets for ANS vegetables and possibly linking farmers to appropriate markets. The results were in concurrence with those of Abukutsa-Onyango (2003).

African nightshades have a short harvesting period but are more prolific in seed production. This is discouraging to producers; however, less or no research has been conducted to develop high-yielding varieties regarding leaves and low seed producers.

\section{Phytochemical concentration}

Phytochemical analysis of plant samples collected from different farms revealed that different nightshade accessions have different phytochemical concentrations (Figures 5 to 8 ).

Solanum villosum had the highest phytochemical concentration in both Kisii and Siaya counties at $61 \%$ and $55 \%$ total antioxidant activity and total phenolic content of 38.8gGAE/Kg DM and 31g GAE/Kg DM, respectively. The lowest total antioxidant activity in Kisii county was recorded in $S$. grossidentatum at $24 \%$, with a total phenolic content of $3.57 \mathrm{gGAE} / \mathrm{Kg}$ DM. Meanwhile, the lowest total antioxidant activity in Siaya county was recorded in $S$. tarderemotum at $16 \%$, with a total phenolic content of $7.46 \mathrm{gGAE} / \mathrm{Kg} \mathrm{DM}$. However, there was great variability in the phytochemical concentration among night accession samples collected from the field.

This shows that the production of various phytochemicals (total phenolic content and total antioxidant activity) may be genetically regulated. Hence, cells activate some responses such as an increase in the expression of genes for antioxidant functions and production of stress proteins, up-regulation of anti-oxidants systems, including antioxidant enzymes, and accumulation of compatible solutes differently in different plants. 


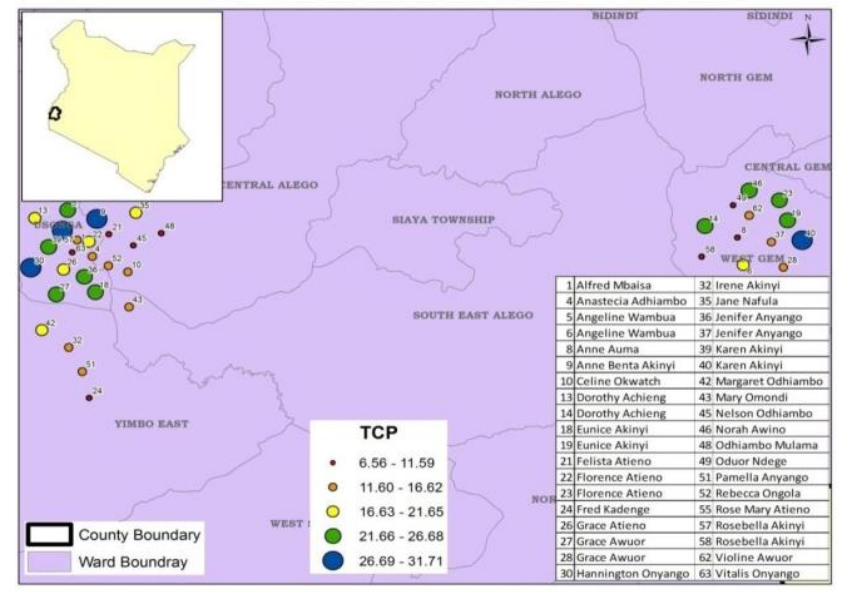

Figure 5. Total phenolic content of different nightshade species as distributed in Siaya County, Kenya

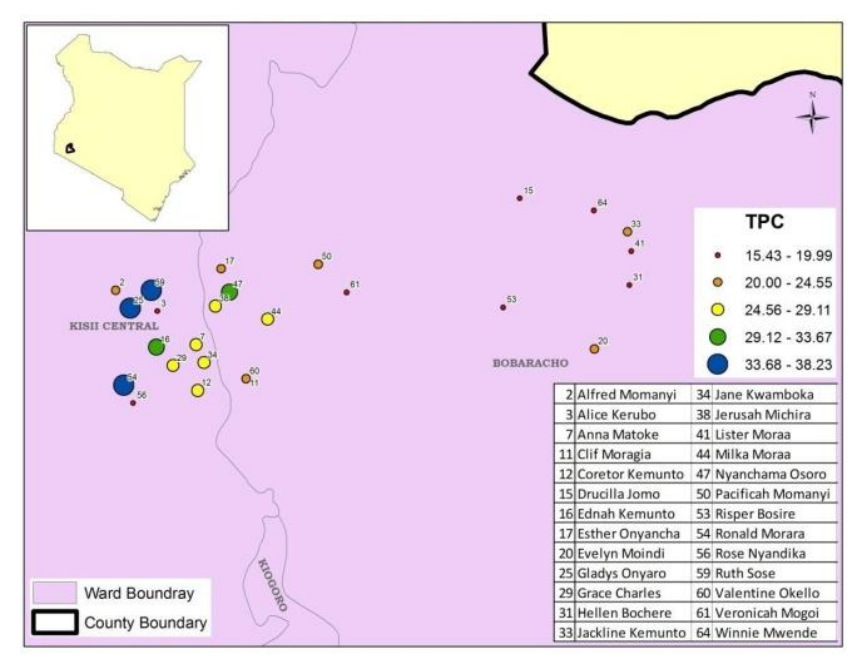

Figure 6. Total phenolic content of different nightshade species as distributed in Kisii County, Kenya

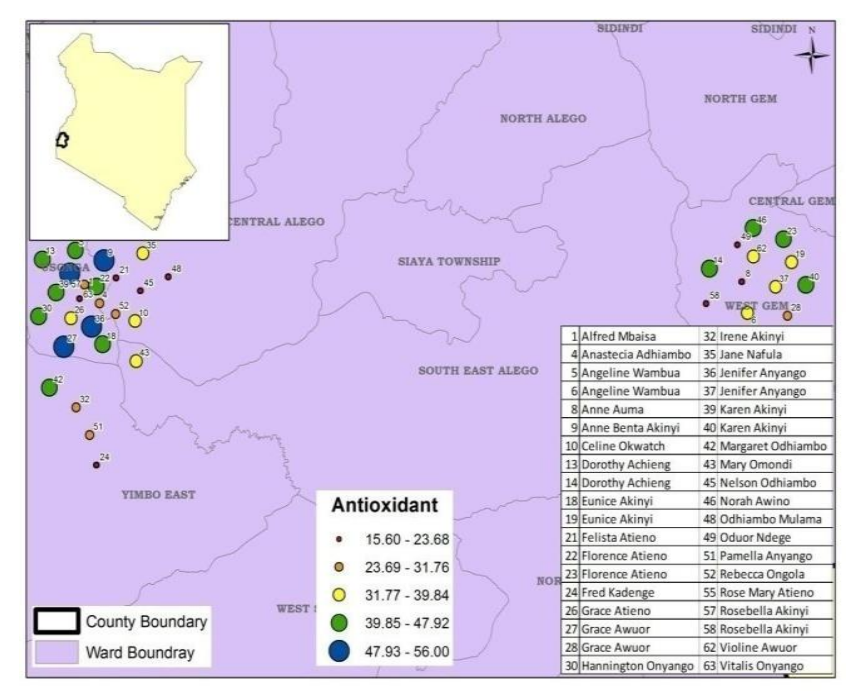

Figure 7. Total antioxidant activity of different nightshade species as distributed in Siaya County, Kenya

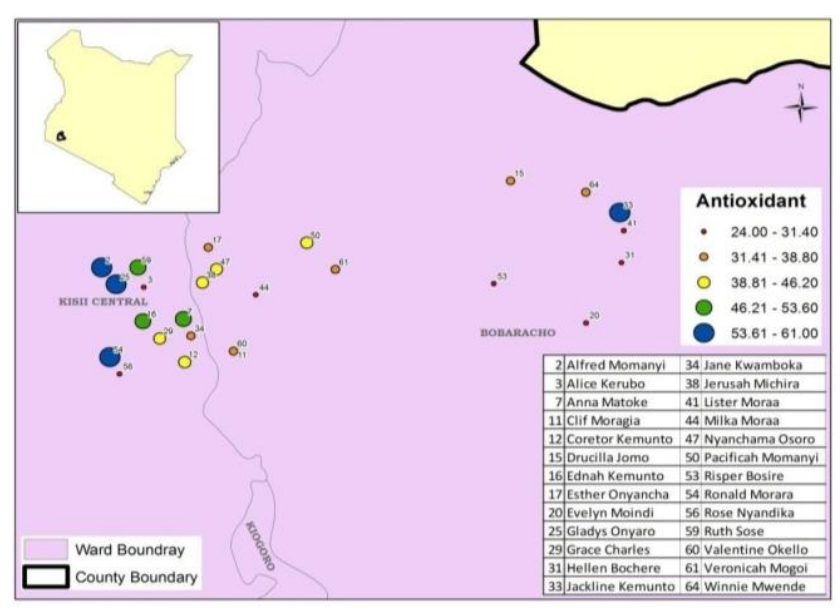

Figure 8. Total antioxidant activity of different nightshade species as distributed in Kisii County, Kenya

Among antioxidant enzymes are catalases (CAT), superoxide dismutase (SOD), peroxidases (POD), ascorbate peroxidases (APX), glutathione reductase (GR), and monodehydroascorbate reductase (MDAR) are prominent (Sairam et al. 2008). Besides, there are antioxidant molecules such as ascorbic acid (AA), glutathione, tocopherols, flavanones, carotenoids, and anthocyanins. Some other compounds like osmolytes (proline), proteins (peroxiredoxin), and amphiphilic molecules (tocopherol) also have ROS scavenging functions and may act as an antioxidant (Mustapha et al. 2014). Non-enzymatic plant antioxidants are either AA-like scavengers or pigments. Some of these compounds are multifunctional; for example, AA can react with $\mathrm{H}_{2} \mathrm{O}_{2}, \mathrm{O}_{2}, \mathrm{OH}$ - and lipid hydroperoxidases and acts as the enzyme co-factor and a donor-acceptor of electrons (Apel and Hirt 2004).

The degree of activities of antioxidant systems under drought stress is extremely variable as the defining factors may include variation in plant species, the cultivars of the same species, development and the metabolic state of the plant, and the duration and intensity of the stress.

\section{Effect of water stress on growth parameters of nightshades Number of secondary buds}

Water stress significantly affected the number of secondary buds at $\mathrm{P} \leq 0.05$ in the greenhouse during long and short rains (Figure 9). The numbers of secondary buds were significantly affected by the different irrigation intervals.

Solanum villosum had the highest number of secondary buds when irrigation was done at a tensiometer reading of 15 cbars. However, Solanum scabrum developed the least number of secondary buds in the greenhouse and both seasons at a tensiometer reading of 85 cbars. The highest mean number of secondary buds of 24 was attained by Solanum villosum under irrigation at a water tension of 15 cba. In comparison, the lowest mean number of secondary buds of 5 was attained by Solanum scabrum under irrigation at a water tension of 85 cbars. Solanum villosum had the highest number of secondary buds at all stress levels measured. There was a significant interaction between water stress and the number of secondary buds (Table 5). 

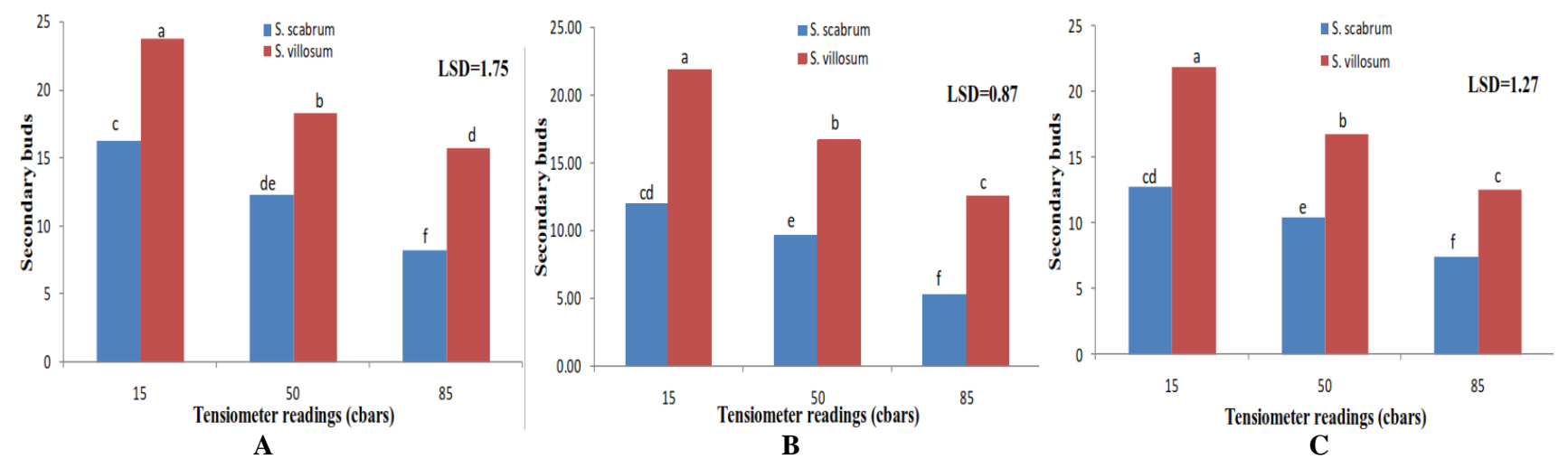

Figure 9. Effects of water stress on the number of secondary buds in (A) greenhouse, B. long rains, and (C) short rains. Bars with different letters were significantly different $(\mathrm{P} \leq 0.05)$.

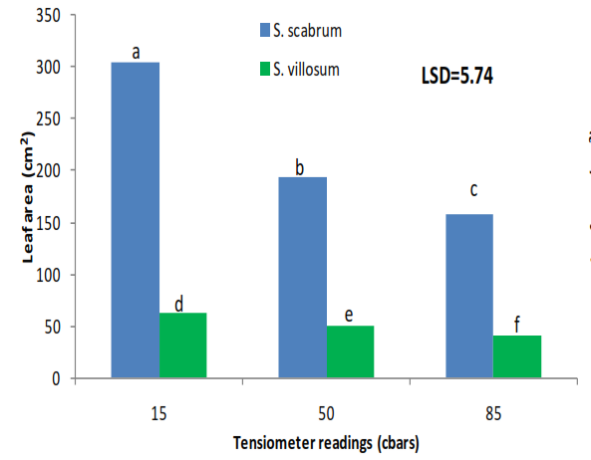

A

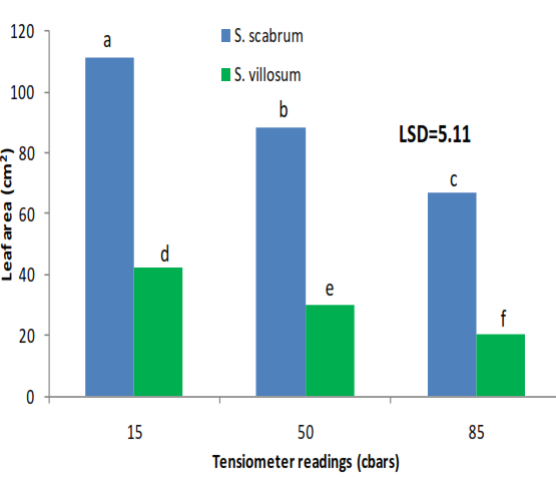

B

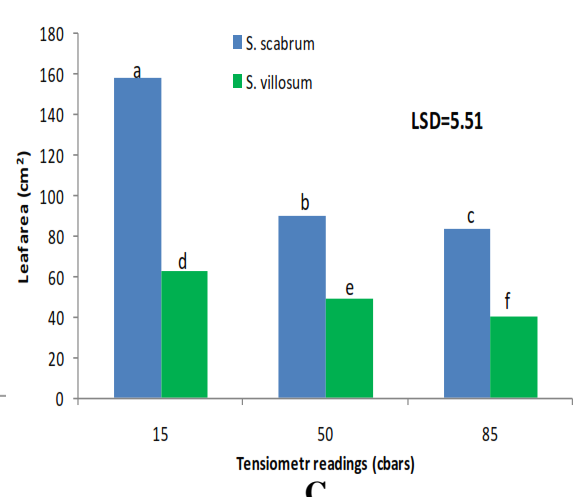

C

Figure 10. Effects of water stress on leaf area in (A) greenhouse, (B) long and short rains. Bars with different letters were significantly different $(\mathrm{P} \leq 0.05)$.

From the obtained data, moisture stress at the vegetative stage significantly reduced branch production in this study. This is in line with Mustapha et al. (2014), who found that water stress reduced branching in selected soya bean genotypes, and Summerfield et al. (1976), who reported that water-stressed cowpea plants were reduced in branching. Reduction in the number of secondary buds can be a phenomenon by the plants to decrease the surface area over which transpiration takes place.

\section{Leaf area}

There was a significant effect at $\mathrm{P} \leq 0.05$ between watering regimes and leaf area in the greenhouse, season one (long rains) and season two (short rains) (Figure 10).

Solanum scabrum had a higher total leaf area of $304.45 \mathrm{~cm}^{2}$ than Solanum villosum of $62.45 \mathrm{~cm}^{2}$ under irrigation at water tension of 15 cbars. The lowest leaf area of $20.62 \mathrm{~cm}^{2}$ was attained in Solanum villosum under irrigation at a water tension of 85 cbars. In moderate water deficit, leaf area among varieties had a declining order of Solanum scabrum > Solanum villosum. S. scabrum leaves had the highest leaf area of all the water stress levels. As soil water tension increased, the leaf area reduced. The reduction in leaf area was more pronounced in S. scabrum when subjected to water stress than in $S$. villosum. There was a significant interaction between irrigation interval and the variety of leaf areas (Table 6).

Leaf area development is directly related to the yield of African nightshades since the edible part is the leaf. Water stress reduces leaf growth by reducing cell division and expansion rates due to turgor loss (Akinci and Lösel 2012). It is well known that as soil water availability is limited, plant growth is usually decreased. This was previously considered due to turgor loss in the expanded cells. However, more recent studies show that stem and leaf growth may be inhibited at low water potential despite complete turgor maintenance in the growing regions due to osmotic adjustment (Tanguilig et al. 1987). This suggests that growth inhibition may be metabolically regulated, possibly serving an adaptive role by restricting the development of transpiring leaf areas in water-stressed plants. The impact of water stress on leaf growth can be explained as a method of adaptation to water shortage conditions to limit the rate of transpiration and maintain the water supply in the soil around plant roots to increase the chance of survival of plants. The mechanism by which plant leaf area is reduced under water stress is by reducing cell elongation, which leads to decreased cell size and, therefore, leaf area reduction (Markhart 1985). 
Table 5. Interactions between irrigation interval and variety on the number of secondary buds

\begin{tabular}{lcccc}
\hline Variety & $\begin{array}{c}\text { Tensiometer Greenhouse } \\
\text { readings } \\
\text { (cbars) }\end{array}$ & $\begin{array}{c}\text { Long rainy } \\
\text { season } \\
\text { Secondary } \\
\text { buds }\end{array}$ & $\begin{array}{c}\text { Short rainy } \\
\text { secondary } \\
\text { buds }\end{array}$ & $\begin{array}{c}\text { Secondary } \\
\text { buds }\end{array}$ \\
\hline $\begin{array}{l}\text { Solanum } \\
\text { scabrum }\end{array}$ & 15 & $16.25 \mathrm{c}$ & $12 \mathrm{~d}$ & $13 \mathrm{~d}$ \\
& 50 & $12.25 \mathrm{e}$ & $9.6 \mathrm{e}$ & $10.47 \mathrm{e}$ \\
& 85 & $8.25 \mathrm{f}$ & $5.25 \mathrm{f}$ & $7.75 \mathrm{f}$ \\
Solanum & 15 & $23.75 \mathrm{a}$ & $21.9 \mathrm{a}$ & $22.47 \mathrm{a}$ \\
villosum & & & & \\
& 50 & $18.25 \mathrm{~b}$ & $16.75 \mathrm{~b}$ & $17.25 \mathrm{~b}$ \\
& 85 & $15.75 \mathrm{~cd}$ & $12.55 \mathrm{c}$ & $13.75 \mathrm{c}$ \\
LSD & & & & \\
TXV & & $\mathbf{1 . 7 5}$ & $\mathbf{0 . 8 7}$ & $\mathbf{1 . 7 4}$ \\
\hline
\end{tabular}

*Means followed by the same letter in a column are not significantly different at $\mathrm{P} \leq 0.05$

Table 6. Interactions between irrigation interval and variety on leaf area

\begin{tabular}{lcccc}
\hline Variety & $\begin{array}{l}\text { Tensiometer } \\
\text { readings } \\
\text { (cbars) }\end{array}$ & Greenhouse & $\begin{array}{l}\text { Long } \\
\text { rainy } \\
\text { season }\end{array}$ & $\begin{array}{c}\text { Short } \\
\text { rainy } \\
\text { season }\end{array}$ \\
\cline { 3 - 5 } & Leaf area & Leaf area & Leaf area \\
\hline $\begin{array}{l}\text { Solanum } \\
\text { scabrum }\end{array}$ & 15 & $304.45 \mathrm{a}$ & $111.27 \mathrm{a}$ & $158.64 \mathrm{a}$ \\
& 50 & $193.61 \mathrm{~b}$ & $88.45 \mathrm{~b}$ & $90.37 \mathrm{~b}$ \\
& 85 & $158.45 \mathrm{c}$ & $66.92 \mathrm{c}$ & $83.41 \mathrm{c}$ \\
Solanum & 15 & $62.45 \mathrm{~d}$ & $42.50 \mathrm{~d}$ & $56.88 \mathrm{~d}$ \\
villosum & & & & \\
& 50 & $49.55 \mathrm{e}$ & $30.16 \mathrm{e}$ & $47.26 \mathrm{e}$ \\
& 85 & $40.81 \mathrm{f}$ & $20.62 \mathrm{f}$ & $35.51 \mathrm{f}$ \\
LSD & & & & \\
TXV & & 5.74 & 5.11 & 5.51 \\
\hline
\end{tabular}

Note: *Means followed by the same letter in a column are not significantly different at $\mathrm{P} \leq 0.05$
Emam et al. (2010) reported a reduction in the leaf area of dry beans when the plants were exposed to drought stress during the vegetative growth stage. Furthermore, Nielsen and Nelson (1998) observed significant leaf area reductions in black beans $(P$. vulgaris $\mathrm{L})$ under drought stress in the vegetative phase. Markhart (1985) also found significant decreases in the leaf area under drought conditions 23 days after planting for two bean species $(P$. vulgaris and P. acutifolius). Muthomi and Musyimi 2009, found leaf area reduction on Solanum scabrum when they subjected the seedlings to water stress. Indeed, loss of leaf area, which could have resulted from the reduced size of younger leaves and inhibition of the expansion of developing foliage, is also considered an adaptation mechanism to moisture deficit (Emam et al. 2010).

\section{Shä height}

Water stress significantly affected shoot height at $\mathrm{P} \leq$ 0.05 in the greenhouse during long and short rains, as in Figure 11. Solanum scabrum produced the tallest plants at all water stress levels.

This was related to the growth habit of this species. However, water stress depressed the plant height of both accessions, and the shortest plants were produced at higher water stress levels. The two varieties differed in height concerning plant height. Solanum scabrum was the tallest $(40.17 \mathrm{~cm})$ under irrigation at 15 cbars, while Solanum villosum was the shortest $(20.24 \mathrm{~cm})$ under irrigation at 85 cbars. The growth reduction in shoot length in irrigation interval at 85 cbars treatment compared to 15 cbars could be associated with a decrease in the cytokinin transport from roots to shoots or the increase in the amount of phytohormone abscisic acid (ABA). The hormone imbalance leads to changes in the cell wall extensibility and a decline in the concentration of photosynthetic enzymes, which results in reduced growth. (Kannan and Kulandaivelu 2011). In Table 7, the interaction between water stress and varieties of shoot height was statistically significant $(\mathrm{P} \leq 0.05)$.
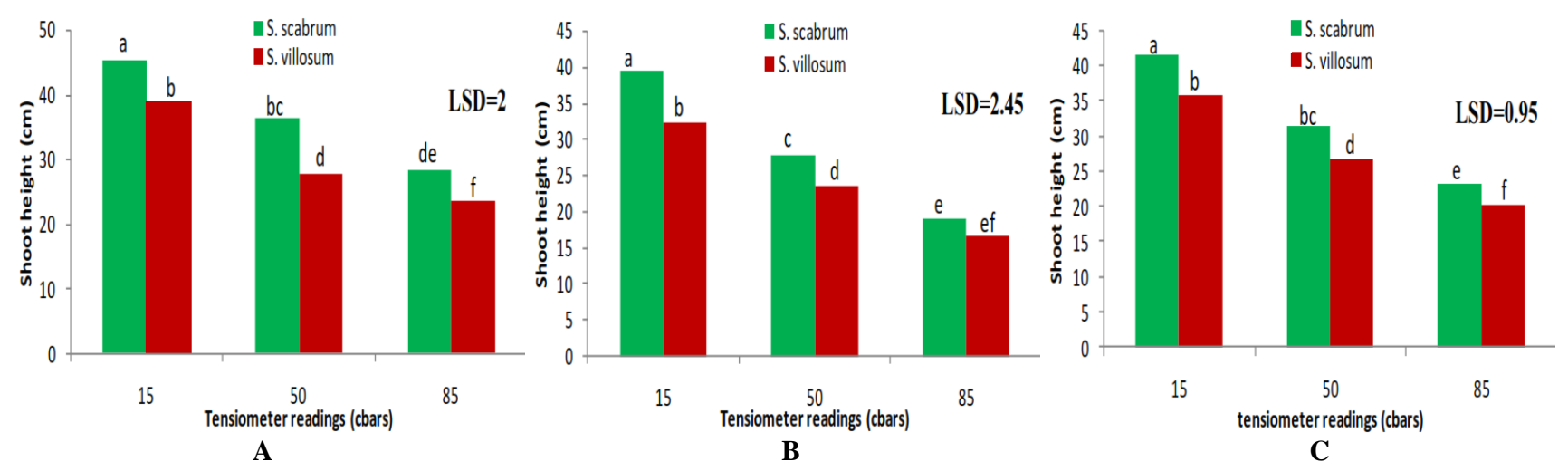

Figure 11. Effects of water stress on shoot height in (A) greenhouse, (B) long rains, and (C) short rains. Bars with different letters were significantly different $(\mathrm{P} \leq 0.05)$ 
Table 7. Interaction between irrigation interval and species on shoot height

\begin{tabular}{lcccc}
\hline \multirow{2}{*}{ Variety } & $\begin{array}{c}\text { Tensiometer } \\
\text { readings (cbars) }\end{array}$ & Greenhouse & $\begin{array}{c}\text { Long } \\
\text { rainy } \\
\text { season }\end{array}$ & $\begin{array}{c}\text { Short } \\
\text { rainy } \\
\text { season }\end{array}$ \\
\cline { 3 - 5 } $\begin{array}{l}\text { Solanum } \\
\text { scabrum }\end{array}$ & 15 & $\begin{array}{c}\text { Shoot } \\
\text { height }\end{array}$ & $\begin{array}{c}\text { Shoot } \\
\text { height }\end{array}$ & $\begin{array}{c}\text { Shoot } \\
\text { height }\end{array}$ \\
& 50 & $35.17 \mathrm{a}$ & $39.49 \mathrm{a}$ & $41.42 \mathrm{a}$ \\
& 85 & $28.29 \mathrm{bc}$ & $27.85 \mathrm{c}$ & $31.24 \mathrm{bc}$ \\
$\begin{array}{l}\text { Solanum } \\
\text { villosum }\end{array}$ & 15 & $39.03 \mathrm{~b}$ & $32.22 \mathrm{~b}$ & $35.64 \mathrm{~b}$ \\
& 50 & $27.79 \mathrm{~d}$ & $23.58 \mathrm{~d}$ & $26.79 \mathrm{~d}$ \\
& 85 & $23.45 \mathrm{f}$ & $16.65 \mathrm{ef}$ & $20.24 \mathrm{f}$ \\
LSD & & & & \\
TXV & & 2 & 2.45 & 0.95 \\
\hline N & & $*$ & $*$ & $*$ \\
\hline
\end{tabular}

Note: *Means followed by the same letter in a column are not significantly different at $\mathrm{P} \leq 0.05$

The effect of water stress on plant height was highly significant. Plant height was decreased at the vegetative stage. This is in concurrence with Desclaux et al. (2000), who found that water stress reduced the number of nodes and the main stem height of soybeans. The result also agrees with Hiler et al. (1972), who found that plant height in cowpea was substantially reduced by water stress. Similarly, a reduction in plant height in response to soil water deficit has been reported for wheat (Day et al. 1978; Abayomi 1992), barley (Day et al. 1978), grain sorghum (Blum et al. 1989, and cowpea (Aderolu 2000). This result is in agreement with the results of Emam (2010), Kannan and Kulandaivelu (2011), Nielsen and Nelson (1998), and Shenkut and Brick (2003), who reported on depression of plant height as a result of the severe stress treatment. Influence of environmental factors such as water stress. Drought stress affects both elongation and expansion growth (Jaleel et al. 2008). Due to the low turgor pressure, water deficiency significantly suppresses cell growth and expansion. Osmotic regulation can enable the maintenance of cell turgor for survival or assist plant growth under severe drought conditions (Shao et al. 2009). The reduction in plant height was associated with a decline in cell enlargement and more leaf senescence (Bhatt and Rao 2005). Stress inhibits the efficiency of the translocation and assimilation of photosynthetic products (Xiong and Zhu 2002) and might have caused a reduction in shoot growth.

\section{Fresh and dry shoot weights}

There was a significant (at $\mathrm{P} \leq 0.05$ ) effect between water stress and the fresh and dry shoot weights (Figure 12). In well-irrigated soils (at 15 cbars), the $S$. scabrum variety had the highest fresh and dry weights of 152.27 and 50.78 , respectively.

The difference in the weights was significant $(\mathrm{P} \leq 0.05)$ among $S$. scabrum and $S$. villosum varieties. In moderate water deficit, the two accessions' fresh and dry shoot weights had a declining order of $S$. scabrum $>S$. villosum. There was a great reduction in weight between fresh and dry shoot weights of $S$. scabrum than S. villosum. This indicates that $S$. scabrum harbors more water in the tissues and is more susceptible to water stress, as seen in the rapid reduction in fresh weight at different irrigation intervals.

Moisture stress reduced the shoot's dry weight (Table 8). Plants under irrigation at 15 cbars had large leaf areas and hence absorbed sufficient sunlight and so likely produced large quantities of dry matter through photosynthesis resulting in high fresh and dry weights compared to those under irrigation at 85 cbars. The reduction in the number of secondary buds, leaf area, and shoot height also significantly reduced shoot fresh and dry weights.

These results agree with the findings of Bradford and Hsiao (1982) and Chartzoulakis et al. (1993). Chartzoulakis et al. (1993) reported similar water stress effects on the dry matter in Kiwi fruit. Other researchers have published similar impacts of water stress on shoot biomass reduction for a range of different agricultural and horticultural crops, including sorghum (Chaudhuri and Kanemasu 1982), tomato (Rumit et al. 2010; peach (Tan and Buttery 1997), and strawberry (Kirnak et al. 2003).
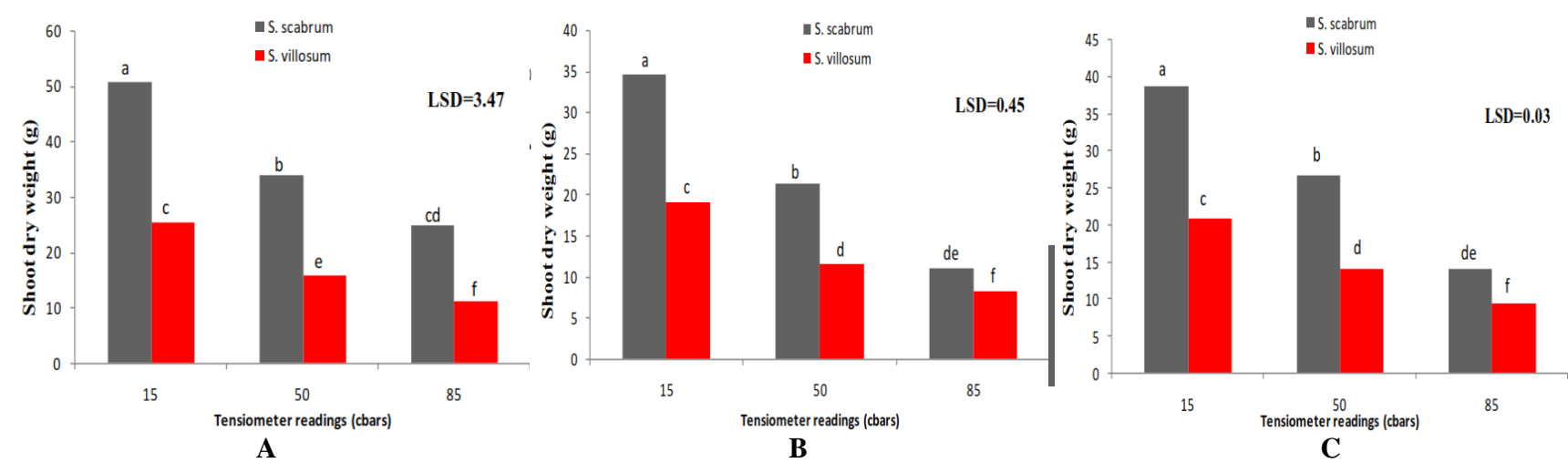

Figure 12. Effects of water stress on shoot dry weight in (A) greenhouse, (B) long rains, and (C) short rains. Bars with different letters were significantly different $(\mathrm{P} \leq 0.05)$ 
Table 8. Interactions between irrigation interval and species on shoot fresh and dry weights

\begin{tabular}{|c|c|c|c|c|c|c|c|}
\hline \multirow[b]{2}{*}{ Variety } & \multirow{2}{*}{$\begin{array}{l}\text { Tensiometer readings } \\
\text { (cbars) }\end{array}$} & \multicolumn{2}{|c|}{ Greenhouse } & \multicolumn{2}{|c|}{ Long rains } & \multicolumn{2}{|c|}{ Short rains } \\
\hline & & $\begin{array}{c}\begin{array}{c}\text { Shoot fresh } \\
\text { weight }\end{array}\end{array}$ & $\begin{array}{c}\text { Shoot dry } \\
\text { weight }\end{array}$ & $\begin{array}{c}\text { Shoot fresh } \\
\text { weight }\end{array}$ & Shoot dry weight & $\begin{array}{c}\text { Shoot fresh } \\
\text { weight }\end{array}$ & Shoot dry weight \\
\hline \multirow[t]{3}{*}{ Solanum scabrum } & 15 & $152.27 \mathrm{a}$ & $50.78 \mathrm{a}$ & $84.21 \mathrm{a}$ & $34.53 a$ & $87.44 a$ & $38.54 \mathrm{a}$ \\
\hline & 50 & $96.72 \mathrm{~b}$ & $33.87 \mathrm{~b}$ & $54.91 \mathrm{c}$ & $21.39 \mathrm{~b}$ & $60.28 b c$ & $26.55 b$ \\
\hline & 85 & $66.35 \mathrm{c}$ & $24.73 \mathrm{~cd}$ & $37.86 \mathrm{ef}$ & $11.02 \mathrm{de}$ & $45.41 \mathrm{c}$ & $14.01 \mathrm{~d}$ \\
\hline \multirow[t]{3}{*}{ Solanum villosum } & 15 & $73.69 \mathrm{~cd}$ & $25.23 \mathrm{c}$ & $58.48 \mathrm{~d}$ & $18.98 \mathrm{c}$ & $61.26 \mathrm{~b}$ & $20.7 \mathrm{c}$ \\
\hline & 50 & $47.68 \mathrm{e}$ & $15.82 \mathrm{e}$ & $38.25 \mathrm{e}$ & $11.45 \mathrm{~d}$ & $44.01 \mathrm{~d}$ & $13.99 \mathrm{de}$ \\
\hline & 85 & $28.63 \mathrm{f}$ & $11.07 \mathrm{f}$ & $26.73 \mathrm{f}$ & $8.16 \mathrm{f}$ & $30.27 \mathrm{e}$ & $9.3 \mathrm{f}$ \\
\hline LSD & & 7.34 & 3.47 & 2.42 & 0.45 & 0.98 & 0.03 \\
\hline TXV & & $*$ & $*$ & $*$ & $*$ & $*$ & $*$ \\
\hline
\end{tabular}

Note: *Means followed by the same letter(s) in a column are not significantly different at $\mathrm{P} \leq 0.05$

The reduction in fresh and dry weights of plants subjected to water stress can be attributed to declining plant shoot height, decreased plant leaf areas, and reduced number of secondary buds.

\section{Fresh and dry root weights}

Water stress significantly affected the two accessions fresh and dry root weights. The effect on the dry and fresh weights was statistically significant at $\mathrm{P} \leq 0.05$.

$S$. scabrum had the highest fresh and dry root weights (18.51 and 7.78, respectively) at irrigation intervals of 15 cbars. The lowest fresh and dry root weights (1.92 and 0.89 , respectively) were recorded in $S$. villosum at an irrigation interval of 85 cbars. However, the reduction due to water stress was minimal compared to the same effect on shoot weight in terms of root weight. Table 9 shows the interaction between the different irrigation intervals and fresh and dry root weight, which was significant $(\mathrm{P} \leq 0.05)$.

Root growth was less inhibited than shoot growth under water stress. This agrees with Kirnak et al. (2003), who reported that some roots continue to elongate at low water potentials that completely inhibit shoot growth. In plants growing in drying soil, root system development is usually less inhibited than shoot growth. Likewise, roots tend to grow thinner under low water potential, and this change in morphology is believed to be adaptive such that roots can further concentrate their use of resources (Sharp 1996).

\section{Effects of water stress on the phytochemical accumulation in nightshades}

\section{Total shoot and phenolic root content}

There was a significant effect of water stress effect $(\mathrm{P} \leq$ 0.05 ) on the total leaf phenolic content (Figure 14).

The different irrigation intervals significantly affected the shoot and root total phenolic content $(\mathrm{P} \leq 0.05)$. Data showed that the highest concentration of total phenolic compounds was in the shoots of $S$. villosum at $46.41 \mathrm{gGAE} / \mathrm{Kg} \mathrm{DM}$ and roots of $S$. scabrum at 25.06gGAE/Kg DM. The phenolic contents of both the roots and leaves increased with increasing water stress levels; hence the highest results were obtained from plants irrigated at 85 cbars. Despite variation in the phenolic contents in different seasons, the trend remained the same (Figure 15).

During water stress, plants activate the synthesis of phenolic compounds (anthocyanin, proline, and flavonoids), carotenoids, and ascorbic acid (Mandal et al. 2009). Thus, phenolic compounds provide essential physiological and ecological functions, mainly involved in protection against different types of stress (Ayaz et al. 2000). Besides numerous enzymes (superoxide dismuthase, peroxidase,

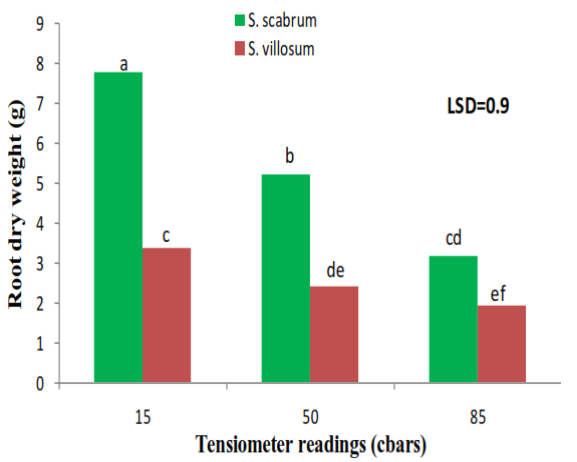

A

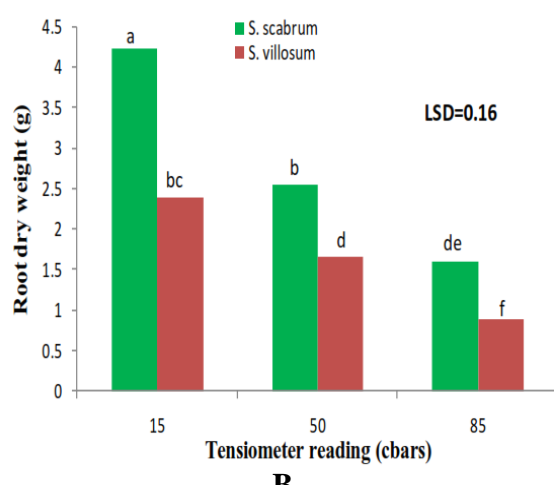

B

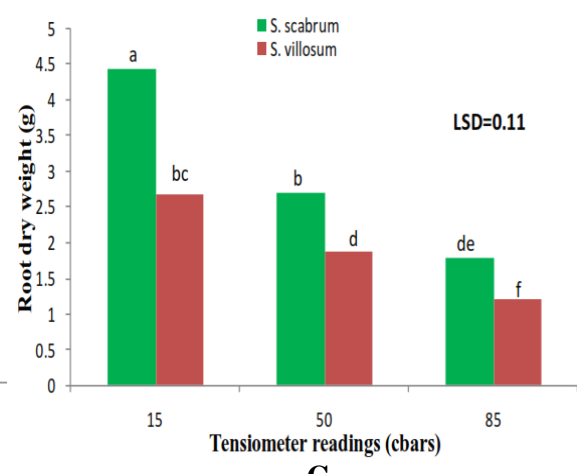

C

Figure 13. Effects of water stress on root dry weight in (A) greenhouse, (B) long rains, and (C) short rains. Bars with different letters were significantly different at $\mathrm{P} \leq 0.05$ ) 
Table 9. Interactions between irrigation interval and variety on root fresh and dry weights

\begin{tabular}{|c|c|c|c|c|c|c|c|}
\hline Variety & $\begin{array}{c}\text { Tensiometer } \\
\text { readings } \\
\text { (cbars) }\end{array}$ & $\begin{array}{c}\text { Greenhouse } \\
\text { Root } \\
\text { fresh weight }\end{array}$ & $\begin{array}{c}\text { Root dry } \\
\text { weight }\end{array}$ & $\begin{array}{c}\text { Long rains } \\
\text { Root } \\
\text { fresh weight }\end{array}$ & $\begin{array}{c}\text { Root dry } \\
\text { weight }\end{array}$ & $\begin{array}{c}\text { Short rains } \\
\text { Root } \\
\text { fresh weight }\end{array}$ & $\begin{array}{c}\text { Root dry } \\
\text { weight }\end{array}$ \\
\hline \multirow{3}{*}{ Solanum scabrum } & 15 & $18.51 \mathrm{a}$ & $7.78 \mathrm{a}$ & $7.78 \mathrm{a}$ & $4.23 \mathrm{a}$ & $12.41 \mathrm{a}$ & $4.43 \mathrm{a}$ \\
\hline & 50 & $8.49 \mathrm{~b}$ & $5.23 \mathrm{~b}$ & $5.23 \mathrm{~b}$ & $2.55 b$ & $7.50 \mathrm{bc}$ & $2.69 \mathrm{~b}$ \\
\hline & 85 & $5.17 \mathrm{bd}$ & $3.17 \mathrm{~cd}$ & $3.17 \mathrm{c}$ & $1.59 \mathrm{de}$ & $5.03 \mathrm{e}$ & $1.78 \mathrm{de}$ \\
\hline \multirow[t]{3}{*}{ Solanum villosum } & 15 & $8.25 b c$ & $3.36 \mathrm{c}$ & $3.36 \mathrm{~cd}$ & $2.39 b c$ & $8.26 \mathrm{~b}$ & $2.67 \mathrm{bc}$ \\
\hline & 50 & $4.47 \mathrm{ce}$ & $2.41 \mathrm{de}$ & $2.41 \mathrm{e}$ & $1.66 \mathrm{~d}$ & $6.23 \mathrm{~d}$ & $1.86 \mathrm{~d}$ \\
\hline & 85 & $3.49 \mathrm{cf}$ & $1.92 \mathrm{ef}$ & $2.23 \mathrm{f}$ & $0.89 \mathrm{f}$ & $2.80 \mathrm{f}$ & $1.19 \mathrm{f}$ \\
\hline LSD & & 3.32 & 0.9 & 0.76 & 0.16 & 0.81 & 0.11 \\
\hline TXV & & $*$ & $*$ & $*$ & $*$ & $*$ & $*$ \\
\hline
\end{tabular}

Note: *Means followed by the same letter in a column are not significantly different at $\mathrm{P} \leq 0.05$

Table 10. Interactions between irrigation interval and variety of shoot and root total phenolic content

\begin{tabular}{|c|c|c|c|c|c|c|c|}
\hline \multirow[t]{2}{*}{ Variety } & \multirow{2}{*}{$\begin{array}{c}\text { Tensiometer } \\
\text { readings (cbars) }\end{array}$} & \multicolumn{2}{|c|}{ Greenhouse } & \multicolumn{2}{|c|}{ Long rainy season } & \multicolumn{2}{|c|}{ Short rainy season } \\
\hline & & STPC & RTPC & STPC & RTPC & STPC & RTPC \\
\hline \multirow[t]{3}{*}{ Solanum scabrum } & 15 & $23.55 \mathrm{f}$ & $9.49 \mathrm{e}$ & $11.26 \mathrm{f}$ & $8.56 \mathrm{e}$ & $13.78 \mathrm{f}$ & $6.92 \mathrm{e}$ \\
\hline & 50 & $29.86 \mathrm{~d}$ & $16.45 \mathrm{c}$ & $19.71 \mathrm{~d}$ & $13.96 \mathrm{c}$ & $24.65 d$ & $13.87 \mathrm{~b}$ \\
\hline & 85 & $38.91 b$ & $21.81 \mathrm{a}$ & $24.53 b$ & $20.17 \mathrm{a}$ & $30.66 \mathrm{~b}$ & $16.67 \mathrm{a}$ \\
\hline \multirow{3}{*}{ Solanum villosum } & 15 & $27.86 \mathrm{de}$ & $7.59 \mathrm{f}$ & $14.24 \mathrm{e}$ & $7.83 \mathrm{f}$ & $22.15 \mathrm{e}$ & $5.57 \mathrm{f}$ \\
\hline & 50 & $36.75 \mathrm{c}$ & $15.28 \mathrm{~cd}$ & $21.37 \mathrm{c}$ & $10.65 \mathrm{~d}$ & $29.87 \mathrm{c}$ & $10.40 \mathrm{~d}$ \\
\hline & 85 & $46.41 \mathrm{a}$ & $18.39 b$ & $32.81 \mathrm{a}$ & $16.62 b$ & $36.26 \mathrm{fa}$ & $13.29 \mathrm{bc}$ \\
\hline LSD & & 2 & 1.17 & 1.21 & 0.51 & 0.15 & 1.23 \\
\hline T X V & & $*$ & $*$ & $*$ & $*$ & $*$ & $*$ \\
\hline
\end{tabular}

Note: *Means followed by the same letter(s) in a column are not significantly different at $\mathrm{P} \leq 0.05$. (STPC- shoot total phenolic content, RTPC- root total phenolic content).
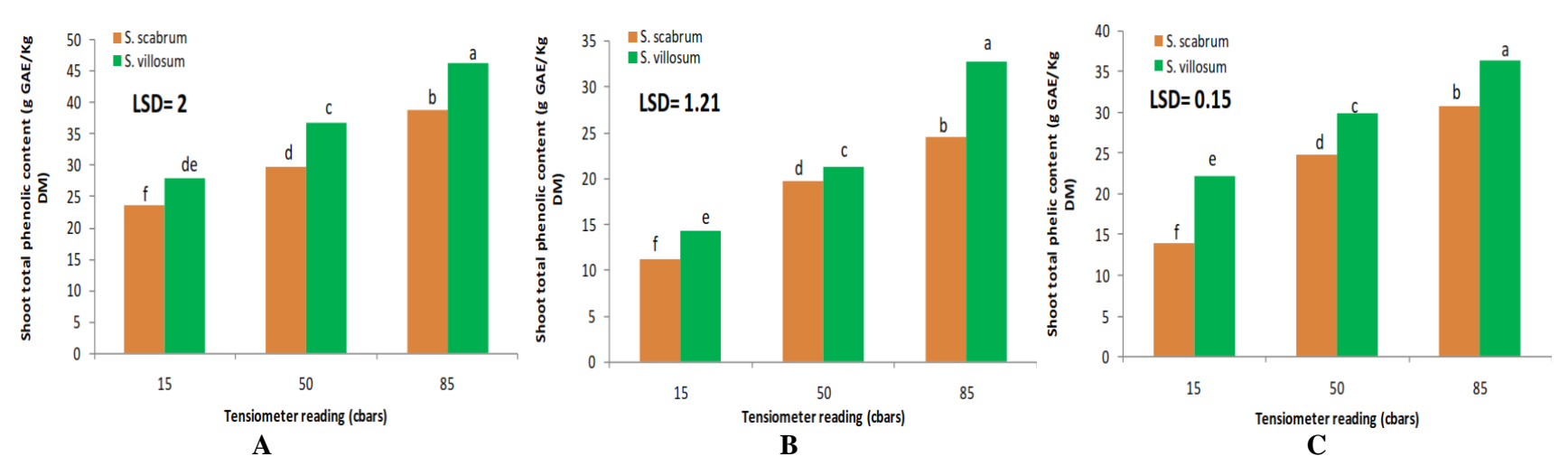

Figure 14. Effects of water stress on shoot total phenolic content in (A) greenhouse, (B) long rains, (B) and (C) short rains. Bars with different letters were significantly different $(\mathrm{P} \leq 0.05)$

etc.), phenolic compounds are potent antioxidants that help plants to survive stress conditions (Mittler 2002). Antioxidant compounds such as phenolic compounds can prevent the oxidative burst of plant cells and thus protect plants from damage to proteins and lipids, DNA, and RNA molecules (Apel and Hirt 2004). In the study, the nightshade species were grown and revealed higher contents of total phenols under water stress conditions. The promotion of the synthesis of phenolic compounds due to drought has been documented in numerous studies (Ayaz et al. 2000; Alexieva et al. 2001; Sánchez-Rodríguezand Rubio- Wilhelmi 2010).

However, Solanum scabrum and Solanum villosum responded differently to the water stress conditions. Solanum scabrum had higher phenolic content in the roots, while Solanum villosum had higher phenolic content in the shoots. This can be explained as the differential partitioning of phenolics in different plant species under stress. Solanum scabrum portioned more phenolics in the roots to act as osmolytes to maintain root cell turgor and increase the osmotic potential that helps keep the gradient for water uptake. The higher phenolic content in the shoots of Solanum villosum would likely help in protecting enzymes, membrane structure, and integrity, scavenging free radicals, and stabilizing cellular macromolecule structures. 
Shoot and root total antioxidant activity

There was a significant influence on watering regimes and the total leaf and root antioxidant activity in the greenhouse during long and short rains (Figure 16, Table $10)$.
Solanum villosum had the highest total antioxidant activity in the leaves at $52.68 \%$, while $S$. scabrum had the highest concentration in the roots at $27.18 \%$ (Figure 17).

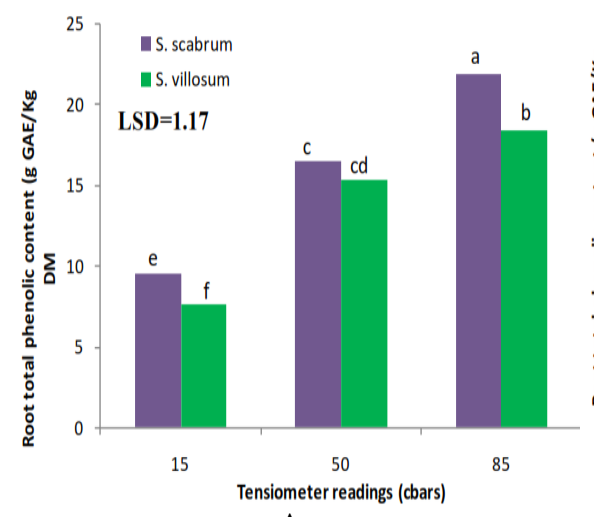

A

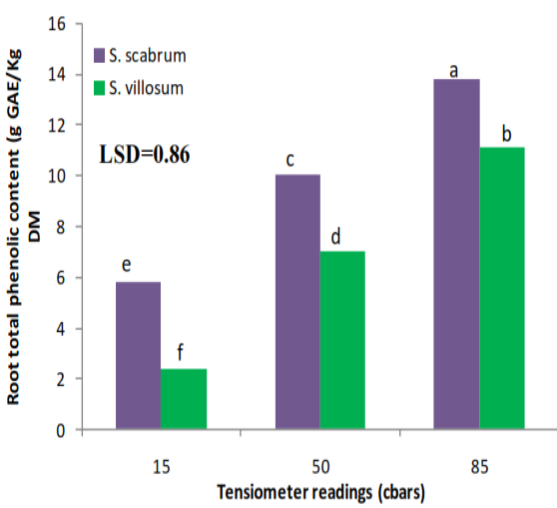

B

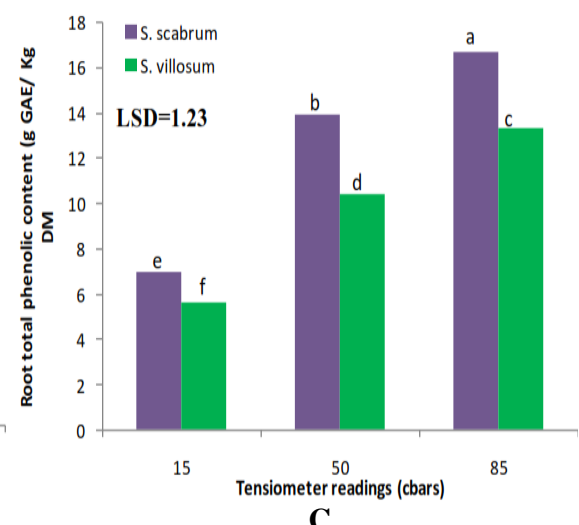

C

Figure 15. Effects of water stress on root total phenolic content in (A) greenhouse, (B) long rains, and (C) short rains. Bars with different letters were significantly different $(\mathrm{P} \leq 0.05)$
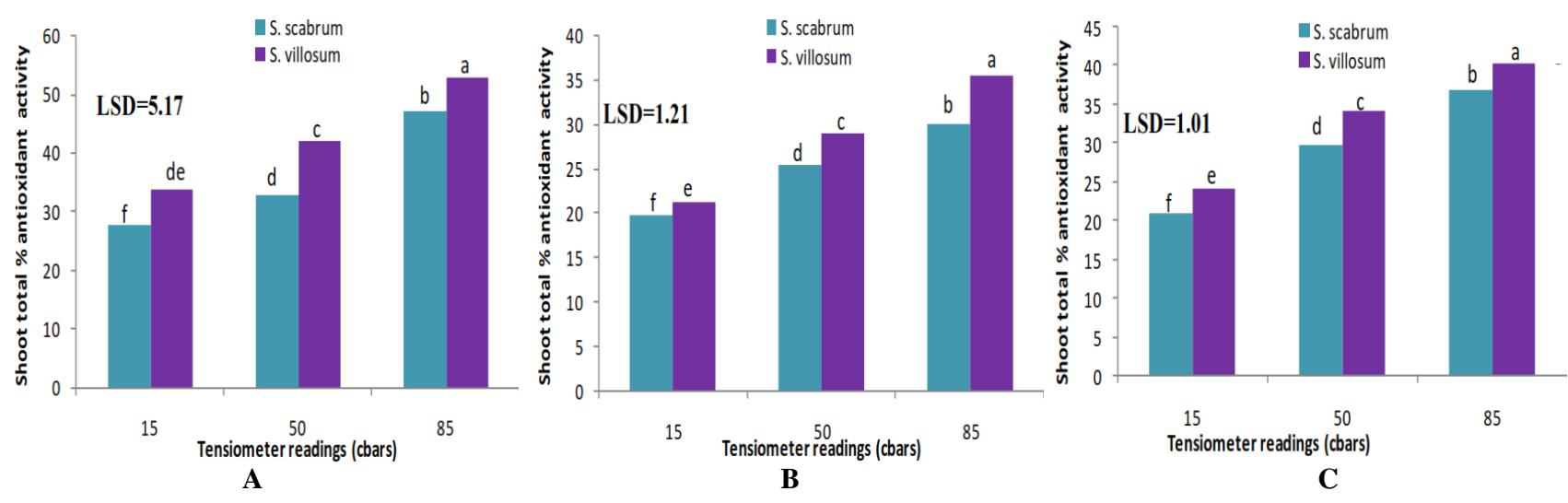

Figure 16. Effects of water stress on the shoot total antioxidant activity in (A) greenhouse, (B) long rains, and (C) short rains. Bars with different letters were significantly different $(\mathrm{P} \leq 0.05)$
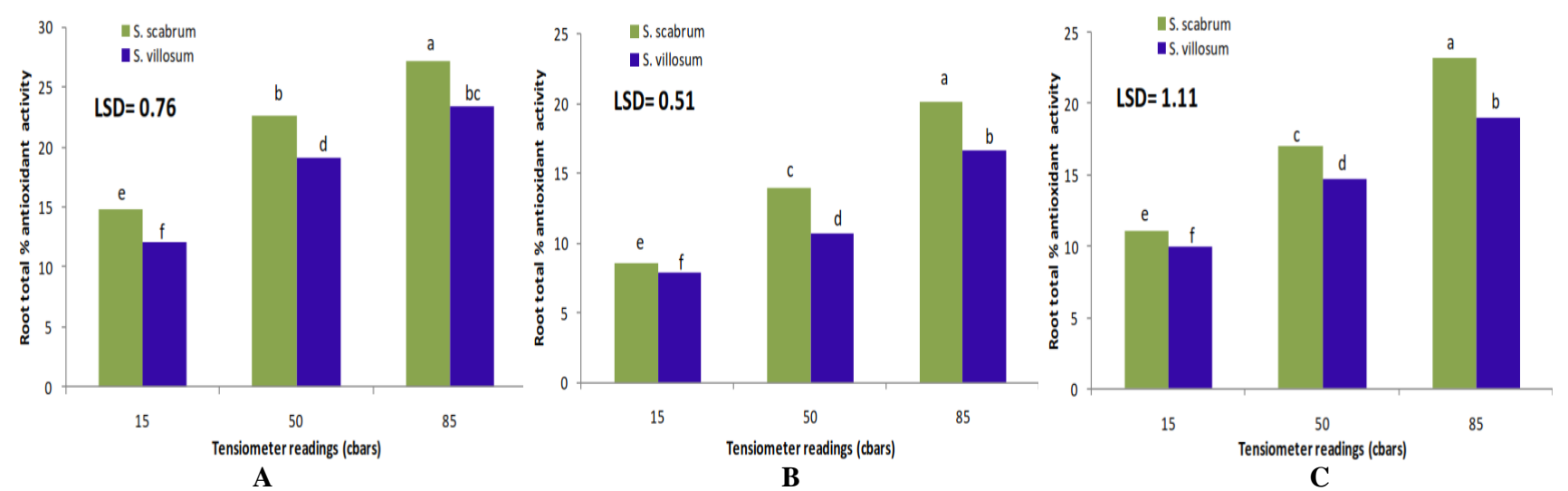

Figure 17. Effect of water stress on the root total antioxidant activity in (A) greenhouse, (B) long rains, and (C) short rains. Bars with different letters were significantly different $(\mathrm{P} \leq 0.05)$ 
Table 4.10. Interactions between irrigation interval and variety on the total shoot and root antioxidant activity

\begin{tabular}{lccccccc}
\hline \multirow{2}{*}{ Variety } & \multirow{2}{*}{$\begin{array}{c}\text { Tensiometer readings } \\
\text { (cbars) }\end{array}$} & \multicolumn{2}{c}{ Greenhouse } & \multicolumn{2}{c}{ Long rainy season } & \multicolumn{2}{c}{ Short rainy season } \\
\cline { 3 - 8 } & 15 & STAA & RTAA & STAA & RTAA & STAA & RTAA \\
\hline Solanum scabrum & 50 & $27.7 \mathrm{f}$ & $14.84 \mathrm{f}$ & $19.83 \mathrm{f}$ & $8.56 \mathrm{e}$ & $21.1 \mathrm{f}$ & $11.05 \mathrm{e}$ \\
& 85 & $42.66 \mathrm{de}$ & $22.59 \mathrm{bc}$ & $25.41 \mathrm{~d}$ & $13.96 \mathrm{c}$ & $29.89 \mathrm{~d}$ & $17.01 \mathrm{c}$ \\
& 15 & $33.04 \mathrm{~b}$ & $27.18 \mathrm{a}$ & $30.14 \mathrm{~b}$ & $20.17 \mathrm{a}$ & $36.87 \mathrm{~b}$ & $23.22 \mathrm{a}$ \\
Solanum villosum & 50 & $41.87 \mathrm{bc}$ & $12.06 \mathrm{e}$ & $21.34 \mathrm{e}$ & $7.83 \mathrm{f}$ & $24.19 \mathrm{e}$ & $9.95 \mathrm{f}$ \\
& 85 & $52.68 \mathrm{a}$ & $23.35 \mathrm{~b}$ & $28.95 \mathrm{c}$ & $10.65 \mathrm{~d}$ & $34.22 \mathrm{c}$ & $14.74 \mathrm{~d}$ \\
LSD & & 5.17 & 0.76 & $1.6 \mathrm{a}$ & $16.62 \mathrm{~b}$ & $40.35 \mathrm{a}$ & $19.04 \mathrm{~b}$ \\
T X V & & $*$ & $*$ & $*$ & 0.51 & 1.01 & 1.11 \\
\hline
\end{tabular}

Note: *Means followed by the same letter(s) in a column are not significantly different at $\mathrm{P} \leq 0.05$. (STAA- shoot total antioxidant activity, RTAA- root total antioxidant activity)

Changes in the antioxidant capacity of water-stressed plants paralleled those in the total phenolic compounds. The changes in the antioxidant capacity of nightshade plants were roughly reflective of the changes in the total phenolic content. At 50 cbars, the total antioxidant activity in the roots among the two species had an increasing order of Solanum scabrum greater than Solanum villosum. In the leaves, the order was Solanum villosum > Solanum scabrum. The lowest levels of total antioxidant activity were recorded in the plants irrigated at 15 cbars. This shows that an increase in water stress led to increased phenolic content in the species grown. The differential in the concentration of total antioxidant activity depended on nightshade species grown, which determines their differential in partitioning as in total phenolic content.

Drought affects not only water relations but also induces stomatal closure and decreases the photosynthetic rate and growth. Closure of stomata decreases $\mathrm{CO}_{2}$ concentration in leaf mesophyll tissue and results in NADPH accumulation. Under such conditions, where $\mathrm{NADP}$ is a limiting factor, oxygen acts as an alternate acceptor of electrons from the thylakoid electron transport chain, resulting in the formation of a superoxide radical $\left(\mathrm{O}_{2}^{-}\right)$(Cadenas 1989). Superoxide radical and its reduction product $\mathrm{H}_{2} \mathrm{O}_{2}$ are potentially toxic compounds and can also combine by the Haber-Weiss reaction to form the highly toxic hydroxyl radical $\left(\mathrm{OH}^{-}\right)$(Sairam et al. 1998).

Under optimal conditions, leaves are rich in antioxidant enzymes and metabolites and can cope with reactive oxygen species (ROS), thus minimizing oxidative damage. Many reports deal with the deleterious effects of ROS, whose production is stimulated under water stress conditions (Malenčić et al. 2000, Blokhina et al. 2003, Foyer and Noctor 2005). ROS causes lipid peroxidation, membrane injuries, protein degradation, and enzyme inactivation (Sairam et al. 2008), thus inducing oxidative stress. Tolerant genotypes, therefore, should not only be able to retain sufficient water under drought but should also have a highly active system to protect against oxidative injury, and Solanum villosum exhibits more of this than Solanum scabrum. Plants possess several tissue antioxidant enzymes for protection against ROS, like superoxide dismutase (SOD), ascorbate peroxidase (APOX), guajkol peroxidase (GPOX), reductase (GR), and catalase (CAT).
These enzymes either quench toxic compounds or regenerate antioxidants with the help of reducing power provided by photosynthesis (Zacchini et al. 2003).

During drought conditions, high activities of antioxidant enzymes are associated with lower levels of lipid peroxidation, being related to drought tolerance (Bowler et al. 1992). An increased metabolic capacity of these enzymes may be part of a general antioxidative system in plants involving the regulation of protein synthesis or gene expression (Foyer et al. 1994, Scandalios et al. 1997). Low-molecular-weight antioxidants are presented by carotenoids, tocopherols, glutathione, and ascorbic acid. Apart from their prominent role as enzyme substrates, they can react chemically with almost all forms of ROS. Among substances able to protect plant cells from oxidative attack, a specific function of polyamines in preventing photooxidative damage is reported (Tadolini 1988; Løvaas 1997). Genotypes of the same species respond differentially to environmental stresses and oxidative injury due to genetic differences in their antioxidant systems, such as in Solanum villosum and Solanum scabrum. That provides a valuable tool for insight into the physiological mechanism operative in stresstolerant genotypes (Sairam et al. 1998).

According to Foyer et al. (1997), much of the injuries caused by exposure to biotic and abiotic stresses are associated with oxidative damage at a cellular level, the chloroplasts being an essential site of $\mathrm{H}_{2} \mathrm{O}_{2}$ generation. Zlatev et al. (2005) established that, at the end of the drought period, an increased $\mathrm{H}_{2} \mathrm{O}_{2}$ and $\mathrm{OH}^{-}$production was observed in young bean plants, therefore revealing a state of oxidative stress in cells. $\mathrm{H}_{2} \mathrm{O}_{2}$ is a strong oxidant produced mainly due to the scavenging of superoxide radicals. Its higher concentration is injurious to cells, resulting in localized oxidative damage, lipid peroxidation, disruption of metabolic function, and losses of cellular integrity at sites where it accumulates (Menconi et al. 1995; Velikova et al. 2000).

It is well known that $\mathrm{H}_{2} \mathrm{O}_{2}$, similar to glutathione, has multi-functional interactive roles in the early stages of the plant stress response. $\mathrm{H}_{2} \mathrm{O}_{2}$ can diffuse relatively long distances, causing changes in the redox status of surrounding cells and tissues that, at relatively low concentrations, it may trigger an antioxidative response 
(Foyer et al. 1997). Rather than just the scavenging capacity, a fine-tuning of $\mathrm{H}_{2} \mathrm{O}_{2}$ levels is essential for efficient control. The rationale of this assumption is that $\mathrm{H}_{2} \mathrm{O}_{2}$, while deleterious to some cellular components, is critical to plants in various biosynthetic reactions and, as suggested by some authors, possibly also in signal transduction pathways, which could contribute to plant defense (Schreck and Baeuerle 1991). The drought-induced production of $\mathrm{H}_{2} \mathrm{O}_{2}$ in the mesophyll cells may be associated with changes in the cell wall structure (Scandalios et al. 1997). Furthermore, $\mathrm{H}_{2} \mathrm{O}_{2}$ is necessary for the peroxidase-mediated oxidative polymerization of cinnamyl alcohols to form lignin. Several enzymatic systems have been proposed as responsible for hydrogen peroxide production on the surface of plant cells (Lütje et al. 2000).

Therefore, it may be suggested that the increased level of $\mathrm{H}_{2} \mathrm{O}_{2}$ observed by many authors in the drought-treated plants is due to oxidative damages but eventually may also have a signal function. $\mathrm{H}_{2} \mathrm{O}_{2}, \mathrm{OH}^{-}$, and other ROS can be expected to be responsible.

For the lipid peroxidation (Zacchini et al. 2003). Sgherri and Navari-Izzo (1995) reported that increased activity of scavenging enzymes could be due either to an adaptive change in catalytic properties or the transcription of the corresponding silent genes. This could be related to enhanced levels of free radicals or other ROS in plant cells and correlate with temporal coordination of the production of $\mathrm{H}_{2} \mathrm{O}_{2}$ via $\mathrm{SOD}$ and destruction of this peroxide by APOX and CAT. Such coordinated responses are believed to promote plant tolerance to oxidative stress (Foyer et al. 1994). It is also possible that increased SOD activity could alter the expression of other metabolic processes associated with water stress. Gupta et al. (1993) have demonstrated that enhanced activity of $\mathrm{Cu}, \mathrm{Zn}$ SOD in transgenic plants was associated with increased activity of APOX. Some other authors also reported an increase in SOD activity in plants under oxidative stress (Gupta et al. 1993; Zlatev et al. 2005).

The relative tolerance of plant genotypes, as reflected by its lower lipid peroxidation and higher membrane stability, is related to the levels of its antioxidant enzyme activity. APOX, Cu, Zn-SOD, and CAT are involved in overcoming oxidative stress. The increased activities of antioxidant enzymes act as a damage control system and, thus, protect from oxidative stress, resulting in lower LPO and higher membrane stability in tolerant genotypes. The literature analyzed in this review complexity of tolerance of plants to water deficit and supports the statements of many authors that the flexibility of cell metabolism and its acclimation to changes in environmental conditions is a first critical step in avoiding stress (Yordanov et al. 2000). The wider the range of adaptation capacity of plants, the better they are protected against various stresses. Plant development program changes are always associated with the physiological and biochemical program and activity changes.

Despite the intensive investigation of the problem of water deficit tolerance, many of its aspects remain to be explored. Water deficit induces expression of particular genes, which is associated in most cases with adaptive responses of stressed plants. The functions of many of them are still not established. Similar results were obtained by Oh (2010) on lettuce seedlings subjected to different water stress levels.

\section{REFERENCES}

Abayomi YA. 1992. Comparative Effect of Water Stress on Wheat and Sugar Beet. [Dissertation]. University of Wales, UK.

Abukutsa-Onyango MO, Tushabomwe-Kazooba C, Mwai W, Onyango GM, Macha ES. 2005. Diversity of African indigenous vegetables with nutrition and economic potential in the Lake Victoria region. In: Oniang'o R, Grum M, Obel-Lawson E. (eds.), Developing African Leafy Vegetables for Improved Nutrition, Regional Workshop, 6-9 December, 2005. Bioversity International, 2007.

Abukutsa-Onyango MO. 2003. Unexploited potential of Indigenous African Vegetables in Western Kenya. Maseno J Educ Arts Sci 4 (1): 103-122.

Aderolu AM. 2000. The effect of water stress at different growth stages on yield and seed quality of cowpea varieties. B. Agric Project University of Ilorin, Nigeria.

Akıncı S, Lösel DM. 2012. Plant Water-Stress Response Mechanisms, Water Stress. Intech, Rijecka, Croatia.

Akter S, Ahmed M, Eun JB. 2010. Solvent effects on antioxidant properties of persimmon (Diospyros kaki L. cv. Daebong) seeds. Intl J Food Sci Technol 45: 2258-2264.

Alexieva V, Sergiev I, Mapelli S, Karanov E. 2001. The effect of drought and ultraviolet radiation on growth and stress markers in pea and wheat. Plant Cell Environ 24: 1337-1344.

Apel K, Hirt H. 2004. Reactive oxygen species: metabolism, oxidative stress, and signal transduction. Ann Rev Plant Biol 55: 373-399.

Ayaz FA, Kadioglu A, Turgut R. 2000. Water stress effects on the content of low molecular weight carbohydrates and phenolic acids in Ctenanthe setosa (Rosc.) Eichler. Canadian J Plant Sci 80: 373-378

Bhatt RM, Rao NKS. 2005. Influence of pod load on response of okra to water stress. Indian J Plant Physiol 10 (1): 54-59.

Blokhina O, Virolainen E, Fagerstedt KV. 2003. Antioxidants, oxidative damage and oxygen deprivation stress: A review. Ann Bot 91: 179194.

Blum A, Shipler L, Golam G, Mayer J. 1989. Yield stability and canopy temperature of wheat genotypes under drought stress. Field Crops Res 22: 289- 296.

Bowler C, Montagu M, Inze D. 1992. Superoxide dismutase and stress tolerance. Ann Rev Plant Physiol 43: 83-116.

Bradford KJ, Hsiao TC. 1982. Physiological responses to moderate water stress. In: Lange O, Nobel PS, Osmond CB, Zeigler $\mathrm{H}$ (eds.). Physiological plant ecology II. Water relations and carbon assimilation. Encyclop Plant Physiol 12B. ed. Springer, Berlin.

Cadenas SE. 1989. Biochemistry of oxygen toxicity. Ann Rev Biochem 58: $79-110$.

Chartzoulakis K, Noitsakis B, Therios I. 1993. Photosynthesis, plant growth, and dry matter distribution in kiwifruit as influenced by water deficits. Irrigation Sci 14: 1-5.

Chaudhuri UN, Kanemasu ET. 1982. Effect of water gradient on sorghum growth, water relations, and yield. Canadian J Plant Sci 62: 599-607.

Day AW, Legg BJ, French BK, Johnson AE, Lawlor DW, Jeffers WD. 1978. A drought experiment using mobile shelters: The effects of drought on barley yield, water use, and nutrient uptake. J Agric Sci Camb 91: 599- 623.

Desclaux D, Huynh TT, Roumet P. 2000. Identification of Soybean characteristics that indicate the timing of drought stress. Crop Sci 40 (3): 716-722.

Emam Y, Shekoofa A, Salehi F, Jalali AH. 2010. Water Stress Effects on Two Common Bean Cultivars with Contrasting Growth Habits. Amer-Eur J Agric Environ Sci 9 (5): 495-499.

Foyer CH, Descourvières P, Kunert K. 1994. Protection against oxygen radicals: an important defense mechanism studied in transgenic plants. Plant Cell Environ 17: 507- 523.

Foyer CH, Lopez-Delgado H, Dat JF, Scott IM. 1997. Hydrogen peroxideand glutathione-associated mechanisms of acclamatory stress tolerance and signaling. Physiol Plant 100: 241-254. 
Foyer CH, Noctor G. 2005. Redox homeostasis and antioxidant signaling: A metabolic interface between stress perception and physiological responses. Plant Cell 17: 1866-1875.

GoK. 1999. National poverty eradication plan 1999-2015. Government of Kenya Printers, Nairobi.

GoK. 2004. Strategy for revitalizing Agriculture 2004-2014: Nairobi, Ministry of Agriculture and the Ministry of Livestock and Fisheries Development, Republic of Kenya, Nairobi.

Gorai M, Hachef A, Neffati M. 2010. Differential responses in growth and water relationship of Medicago sativa (L.) cv. Gabès and Astragalus gombiformis (Pom.) under water-limited conditions. Emir J Food Agric 22 (1): $1-12$

Gupta AS, Webb R P, Holaday AS, Allen D. 1993. Over expression of SOD protects plants from oxidative stress. Induction of ascorbate peroxidase in superoxide dismutase over expressing plants. Plant Physiol 103: 1067-1073.

Hiler EA, Bavel CHM, Hossain MM, Jordan WR. 1972. Sensitivity of Southern peas to water deficits at three growth stages. Agron J 64: 6064.

Imungi JK. 2002. The brighter side of phenolic compounds abundance in African leafy vegetables. Nairobi, IPGRI Newsletter for sub-Saharan Africa 17: 205- 210

Irungu C, Mburu J, Maundu P, Grum M, Hoescle-Zeledon I. 2007. Analysis of Markets for African Leafy Vegetables within Nairobi and its Environs and Implications for On-farm Conservation of Biodiversity. A consultancy report for Global Facilitation Unit for Underutilized Species, Rome, Italy.

Jaleel CA, Sankar B, Murali PV, Gomathinayagam M, Lakshmanan GMA, Panneerselvam R. 2008. Water deficit stress effects on reactive oxygen metabolism in Catharanthus roseus;impacts on ajmalicine accumulation. Colloids Surf B: Biointerfaces 62: 105-111.

Kameli A. 1990. Metabolic Responses of Durum Wheat to Water Stress and their Role in Drought Resistance. [Dissertation]. University of Sheffield, U.K.

Kannan ND, Kulandaivelu G. 2011. Drought induced changes in physiological, biochemical, and phytochemical properties of Withania somnifera Dun. J Med Plants Res 5 (16): 3929-3935.

Kimiywe J, Waudo J, Mbithe D. 2006. Reducing hidden hunger and malnutrition through traditional foods. Nairobi, IPGRI Newsletter for sub- Saharan Africa 21: 75-84.

Kirnak H, Kaya C, Higgs D, Tas I. 2003) Responses of drip irrigated bell pepper to water stress and different nitrogen levels with or withou mulch cover. J Plant Nutr 26: 263-277.

Løvaas E. 1997. Antioxidative and metal-chelating effects of polyamines. Adv Pharmacol 38: 119-149.

Lütje S, Böttger M, Döring O. 2000. Are plants stacked neutrophyles? Comparison of pathogen induced oxidative burst in plants and mammals. In: K Esser J, Kadereit W, Lütge U, Runge M (eds.). Prog Bot 61: 187-222.

Malenčić D, Gašić O, Popović M, Boza P. 2000. Screening for antioxidant properties of Salvia reflexa Hornem. Phytother Res 14: 546-548.

Mandal S, Yadav S, Yadav S, Nema RK. 2009. Antioxidants: A Review. J Chem Pharmacol Res 1: 102-104.

Markhart HA. 1985. Comparative water relations of Phaseolus vulgaris L. and Phaseolus acutifolius Gray. Plant Physiol 77: 113-117.

Maundu PM, Ngugi GW, Kabuye CH. 1999. Traditional Food plants of Kenya. KENRIK, National Museums of Kenya, Nairobi.

Maundu PM, Njiro EI, Chweya JA, Imungi JK, Seme EN. 1999. The Kenyan case study. In: Chweya JA, Eyzaguirre PB. (eds.). The Biodiversity of Traditional Leafy Vegetables. IPGRI,Rome.

Menconi M Sgherri CL Pinzino, Navari-Izzo F. 1995. Activated oxygen production and detoxification in wheat plants subjected to a water deficit programme. J Exp Bot 46: 1123-1130.

Mittler R. 2002. Oxidative stress, antioxidants, and stress tolerance. Trends Plant Sci 7: 405-410.

Mustapha Y, Biwe E R, Salem A. 2014. Effects of moisture stress on the growth parameters of soybean genotypes. Discourse J Agric Food Sci 2 (5): 142-148

Muthomi J, Musyimi DM. 2009. Growth responses of African nightshade (Solanum scabrum Mill) Seedlings to water deficit. ARPN J Agric Biol Sci 4(5): 24-30

Mwaura SN, Muluvi SA, Mathenge MK. 2013. African Leafy Vegetables and Household Wellbeing in Kenya: A Disaggregation by Gender.
The 4th International Conference of the African Association of Agricultural Economists, Tunisia

Nielsen DC, Nelson NO. 1998. Black bean sensitivity to water stress at various growth stages Crop Sci 38: 422-427.

Oh MM, Edward EC, Rajashakar CB. 2010. Regulated water deficit improve phytochemical concentration in lettuce. Amer Soc Hort Sci 1135: 223-229.

Olembo, NK, Fedha SS, Ngaira ES. 1995. Medicinal and Agricultural Plants of Ikolomani Division, Kakamega District, Kenya. Development Partners, Kakamega, Kenya.

Otieno DJ, Omiti J, Nyanamba T, McCullough E. 2009. Market participation by vegetable farmers in Kenya: A comparison of rural and peri-urban areas. African J Agric Res Vol 4 (5): 451-460.

Rispail N, Moris P, Webb K J. 2005. Phenolic compounds- extraction and analysis. In: Lotus japonicus Handbook. Márquez AJ, Stougaard J, Udvardi MK, Parniske M, Spaink HP, Saalbach G, Webb KJ, Chiurazzi M , Márquez AJ. (eds.). Springer, Dordrecht, The Netherlands

Rumit S, Heena K, Rajal S, Naveen S. 2010. In vitro Antioxidant Activity of Roots of Tephrosia Purpurea Linn. International Journal in Pharmacy Sciences 2: 30-33.

Sairam R, Deshmukh P, Saxena D C. 1998. Role of antioxidant systems in wheat genotypes tolerance to water stress. Biol Plant 41: 387-394.

Sairam RK, Kumutha D, Ezhilmathi K, Deshmukh PS, Srivastava GC. 2008. Physiology and biochemistry of waterlogging tolerance in plants. Biol Plant 52: 401-412.

Sánchez-Rodríguez E, Rubio-Wilhelmi M. 2010. Genotypic differences in some physiological parameters symptomatic for oxidative stress under moderate drought in tomato plants. J Plant Sci 178: 30-40.

Scandalios JG, Guan L, Polidoros AN. 1997. Catalases in plants: gene structure, properties, regulation, and expression. In: J G Scandalios (Ed.). Oxidative stress and the molecular biology of antioxidant defenses. Cold Spring Harbor Laboratory Press. New York.

Schippers RR. 2002. African indigenous vegetables, an overview of the cultivated species. Chatham, UK. Natural Resources Institute /ACPEU Technical Centre for Agricultural and rural Cooperation.

Schreck R, Baeuerle PA. 1991. The role of oxygen radicals as second messengers. Trends Cell Biol 1: 39-42.

Sgherri CL M, Navari-Izzo F. 1995. Sunflower seedlings subjected to increasing water deficit stress: oxidative stress and defense mechanisms. Physiol Plant 93: 25- 30

Shao HB, Chu LY, Jaleel CA, Manivannan P, Panneerselvam R, Shao MA. 2009. Understanding water deficit stress-induced changes in the basic metabolism of higher plants - biotechnologically and sustainably improving agriculture and the eco-environment in arid regions of the globe. Crit Rev Biotechnol 29: 131-151.

Sharp RE. 1996. Regulation of plant growth responses to low soil water potential. Hort Sci 31(1): 36-38.

Shenkut AA, Brick MA. 2003. Traits associated with dry edible bean (Phaseolus vulgaris L.) productivity under diverse soil moisture environments. Euphytica 133: 339-347.

Summerfield RJ, Huxley PA, Dart PJ, Hughes. 1976. Some effect of environmental stress on seed of cowpea (Vigna unguiculata (L) Walp). Prima Plant Soil 44: 527-546.

Tadolini B. 1988. Polyamine inhibition of lipid peroxidation. Biochem J 249: 33-36.

Tan WX, Blake TJ. 1997. Gas exchange and water relations responses to drought of fast and slow growing black spruce families. Canadian J Bot 75: 1700-1706.

Tanguilig VC, Yambao E B, O' Toole J C, De Datta S K. 1987. Water stress effects on leaf elongation, leaf water potential transpiration, and nutrient uptake of rice, maize, and soybean. Plant Soil 103: 155-168.

Velikova V, Yordanov I, Edreva A. 2000. Oxidative stress and some antioxidant systems in acid rain-treated bean plants. Protective role of exogenous polyamines. Plant Sci 151: 59-66.

Xiong L, Zhu J K. 2002. Molecular and genetic aspects of plant responses to osmotic stress. Plant Cell Environ 25(2): 131-139.

Yordanov I, Velikova V, Tsonev T. 2000. Plant responses to drought, acclimation, and stress tolerance. Photosynthetica 38: 171-186.

Zacchini M, Rea E, Tullio M, De Agazio M. 2003. Increased antioxidative capacity in maize during and after oxidative stress induced by a long lead treatment. Plant Physiol Biochem 41: 49-54.

Zlatev Z. 2005. Effects of water stress on leaf water relations of young bean plants. J Central Europe Agric 6 (1): 5-14. 